\title{
Visions of Reconstruction
}

\section{Layers of Moving Images}

\author{
Floris Paalman \\ Department of Media Studies \\ University of Amsterdam \\ Turfdraagsterpad 9 \\ 1012 XT Amsterdam \\ The Netherlands \\ f.j.j.w.paalman@uva.nl
}

\begin{abstract}
After WWII, films accompanied the reconstruction of Europe's destroyed cities. Many contained historical footage. How was this material used to articulate visions of reconstruction, what happened to the material later on, and how do these films relate to the city film archive? This question is approached in terms of collective cognitive functions, applied to a media archaeological case study of Rotterdam. In focus are two audio-visual landmarks, a municipally sponsored 'film suite' from 1950 and a television documentary from 1966, as well as their historical footage, all with different temporal horizons. This study attempts to position the city film archive in media history.
\end{abstract}

Keywords: municipal film archive; city film; compilation film; reconstruction; Rotterdam; media archaeology.

\section{Introduction}

The reconstruction of Europe's cities after World War II has mainly been considered as a physical affair. However, reconstruction plans needed images to imagine the future city, provide direction, explain the plans and gain support, and monitor the results once the plans were carried out. Various reconstruction films made use of historical footage to show what had happened and how it had been before, in order to know what to reconstruct or what to build instead. Questions arise about where the footage came from, how it was collected, and by whom. Did it raise controversies? How was it institutionally supported? What happened to the footage later on? Most importantly, do these films, and television productions later on, mark the beginning and development of the city film archive? Although such archives are common today, only rarely have they been discussed in the literature. ${ }^{1}$

These questions raise a more fundamental question. Why do cities need to archive moving images? If the explanation is that moving images fulfil a memory function, this implies that cities need a memory function. As such, a distinction is made vis-à-vis the country with its national archives, which fulfil a memory function within another collective body with

1 As a general term, one could speak of the 'city film archive,' which could be either a private or public archive, although it is in most cases closely related to a municipality and its municipal archives. In this study, its use is immediately linked to the municipal archive of the city of Rotterdam, which has existed since 1857. I will therefore use more specifically the term 'municipal film archive.' In any case, city film archives, in general, may hold relatively large numbers of non-fiction films made for local purposes, which may have excluded the films from being collected by national institutions; see e.g. (with reference to the Antwerp City Archive) Daniel Biltereyst and Roel Vande Winkel, "Lighting Out a Collective Past: To Find, Preserve and Research Flemish Non-fiction Films," Journal of Film Preservation, 62, 2001, 17-21. Despite the large numbers of film collections in city archives, a relatively small number of them are members of the FIAF (International Federation of Film Archives); city archives comprise 10 out of the 145 members of FIAF in 2007), Christian Dimitriu, "The Leviathan and the Identikits: Global Figures for Everyday Use," Journal of Film Preservation, 73 , 2007, 6-18, p.9. City archives are occasionally mentioned in the Journal of Film Preservation. 
other geographical markers. Such a reasoning corresponds to sociological system theory; a basic asset of the theory is to make a distinction between a system and its environment, which in this case could be city and country, or city and world. Within urban studies, various models are being developed to understand the city as a system in spatial and organizational terms. ${ }^{2}$ However, regarding moving images and their preservation, which point to the memory function, the city as a system should also be understood in terms of its collective cognitive functions.

Within film studies as well, attempts have been made to elaborate on system theory. According to Mikkel Eskjær: "Cinema offers a way of looking at the world. This way of looking is an observation of reality, being itself a part of the social world it observes." ${ }^{3}$ In Eskjær's view, with reference to Dirk Baecker, a shift occurs from an (ontological) reality claim of the moving image to an (ontogenetic) claim of "how a phenomenon is produced." ${ }^{4}$ Such a claim has subsequently been made by others, for example by Malte Hagener, to discuss "the interactions, cooptations and dependencies of the avant-garde within a public media arena." ${ }^{5}$ In this approach, system theory mainly provides an organizational model for how the media world works, following Niklas Luhmann's sociological system theory. ${ }^{6}$ However, in their book Film Theory, Malte Hagener and Thomas Elsaesser elaborate on this theory by drawing a connection to film itself as well. In their book they "discuss numerous separations and thresholds between the universe of the film and the 'real world': spatial, architectural, institutional, economic and textual." 7 Film creates a separation, a distance to be able to observe the system. When the observer is part of the system, this is an act of self-reference and self-monitoring.

Luhmann's theory is based on autopoiesis (self-creation), which is the capacity of a system to reproduce and maintain oneself. When an 'irritation' occurs, the system registers the problem and reacts on it, in order to solve the problem and to re-establish equilibrium. This model, however, hardly allows for change. It presupposes that a system, once disturbed, would recreate its initial condition. Within urban studies, a city actually appears to be an adaptive system. So the question is how it can adapt and develop, and how do media take part in this? For purposes of adaptation and development, historical assessment is necessary. This requires a memory function, but also a capacity to evaluate and to provide direction, which is another function that I will discuss. This leads to another problem: who or what in the system is able to do so? This is the problem of agency, which is not solved by Luhmann's theory. In his view, the system exists more or less independently from its constituents, and so he separates society from individuals. I would argue that these cannot be disconnected and that multiple individual acts, just like contingent events, actually account for the dynamics of a system.

Within conventional film history, the emphasis has been on auteurs. Within media archaeology, in its turn, media are seen in connection to their context. However, media archaeologists following system approaches often emphasize media technology, at the expense of media content (and their makers). ${ }^{8}$ Moreover, this media archaeological interest is closely related to digital networks. I will argue, however, that adaptive systems and the networks of which they consist are intrinsic to the history of film and television when seen from a local perspective.

The proposed theoretical model will be elaborated through a case study of Rotterdam. To see it as a system, it should be distinguished from its environment: the country, and the world. After WWII, the city was internationally heralded as a

2 Current system theories regarding society and culture, including cities, are based on complexity, adaptation, and evolution, see e.g., Niklos Salingaros, Principles of Urban Structure, Techne Press, 2005; Sergio Conti, "A Systemic Perspective on Local Development," in Ron Boschma \& Robert Kloosterman, eds., Learning from Clusters: A Critical Assessment from an Economic-Geographical Perspective, Springer, 2005, 19-45; Stephen Marshall, Cities, Design \& Evolution, Routledge, 2009; Roberta Comunian, "Rethinking the Creative City: The Role of Complexity, Networks and Interactions in the Urban Creative Economy," Urban Studies, 48, 6, May 2011, 1157-1179.

3 Mikkel Eskjær, 'Observing Movement and Time-Film Art and Observation,' in Anne Jerslev, ed., Realism and 'Reality' in Film and Media, Museum Tusculanum Press, University of Copenhagen, 2002, 117-138, p. 117.

4 Ibid.

5 Malte Hagener, Moving Forward, Looking Back: The European Avant-garde and the Invention of Film Culture, 1919-1939, Amsterdam University Press, 2007, p. 27.

6 Niklas Luhmann, The Reality of the Mass Media, Stanford University Press, 2000.

7 Thomas Elsaesser and Malte Hagener, Film Theory: An Introduction through the Senses, Routledge, 2010, p. 37.

8 For the discussion of media in terms of systems, see e.g., "Part III: Between Analogue and Digital" in Erkki Huhtamo and Jussi Parikka, eds., Media Archaeology: Approaches, Applications, and Implications, University of California Press, 2011. For my argument here, see also the critique on the work of Wolfgang Ernst by Ken Griffin, "The Lessons of Counterpoint: Wolfgang Ernst's Media Archaeology and Television Archive Research," VIEW, 4, 7, 2015, 11-20. 
model of urban planning by various kinds of films, including Marshall films, in the early $1950 \mathrm{~s},{ }^{9}$ and a range of television productions from the Netherlands and abroad in the 1960s. ${ }^{10}$ Although such productions have been important for the representation of the city within the larger 'environment', and several have indeed become canonical within Dutch film history, ${ }^{11}$ I will focus on films that have received less critical exposure but have been of special importance within the city itself. More specifically, I will consider productions that made use of historical footage and by doing so became interrelated with each other, with the municipal archive as their common base. ${ }^{12}$ However, these productions also emerged through connections between the city and its environment, which I will explain.

The focus will be on two audio-visual landmarks that represent different periods. The first is En toch... Rotterdam ('And Still... Rotterdam,' 1950), ${ }^{13}$ a film commissioned by the municipality to promote the new city plan as envisioned by the city's enlightened business elite. The second one is the independently made television documentary Stad Zonder Hart ('Town without a Heart,' 1966), ${ }^{14}$ which evaluated the plan. Their discourses will be compared and since both productions used in part the same historical footage, layers of moving images will be made visible. Through various records ${ }_{1}^{15}$ the found footage is traced and positioned vis-à-vis emerging archiving practices. While this approach takes into account the content of media, it is not primarily based on textual analysis. ${ }^{16}$ This media archaeological excavation ${ }^{17}$ lays bare the texture of intermingled times and discourses, and the role played in this by the municipality.

In this way I will argue that film and television, in connection to each other, have fulfilled collective cognitive functions within the city. By doing so, film and television have helped to create a framework for urban development. Moreover, these functions can explain the existence of a municipal film archive in a city like Rotterdam. Although the scope of this paper is restricted to a single case study, I present the hypothesis that cities like Rotterdam, destroyed during the war, have been at the forefront of establishing city film archives.

\section{The Void, a Matter of Projection}

When a city is considered as a system, it is distinguished from its environment, but it is not detached from it. Being one of Europe's main port cities, Rotterdam has always been part of larger networks and developments elsewhere have affected the city's development. This was most radically the case on the $14^{\text {th }}$ of May 1940 , when the German Luftwaffe

9 As part of the Marshall plan, over 300 films were made about and accompanying the reconstruction of Europe after WWII, see the Marshall film database: http://ww.marshallfilms.org. The films were made by or for the United States ECA/MSA for promotional purposes to show the achievements of the plan. Among the films that show Rotterdam are Twenty Hours a Day (1950, Albert Brosens), Somewhere to Live (1950, Jacques Brunius), and especially Steady! (1952, Herman van der Horst), which became an international success and a landmark in Dutch documentary cinema, see Bert Hogenkamp, De Documentaire Film 1945-1965: De bloei van een filmgenre in Nederland, 010 Publishers, 2003, p. 101. 10 One well-known example is the television series Lewis Mumford on the City (1963, lan MacNeill/National Film Board of Canada); Rotterdam is shown in (a.o.) the first of the six parts, called The City: Heaven and Hell; similar projects were carried out in Europe as well, e.g., the Eurovision series Town Building and Planning, including the report Rotterdam (1964, Walter Klapper), produced by the Austrian ORF and the European Broadcasting Union.

11 Hogenkamp, 2003.

12 Until 2012, the archive of the city of Rotterdam was called Gemeentearchief Rotterdam (GAR): Municipal Archive Rotterdam. Since 2012, it is called Stadsarchief Rotterdam (City Archive Rotterdam). Its film collection is called 'Collectie Bewegend Beeld' (Moving Image Collection); it includes all kinds of formats and it makes no (categorical) distinction between films, videos or productions originally made for television.

13 En toch... Rotterdam: Een filmsuite van journaals en documentaires uit de jaren 1925-1950, 1950, 45', 35mm, b-w, prod.: Polygoon-Profilti, for: Bureau Voorlichting en Publiciteit, coll.: Stadsarchief Rotterdam, BB-0681.

14 Stad zonder hart, 1966, 47', 16mm, b-w, dir.: Jan Schaper, prod.: Open Studion, broadcast by NCRV, 14 May 1966, coll.: Stadsarchief Rotterdam, BB-0751.

15 Especially important have been the various collections of the Stadsarchief Rotterdam, Nederlands Instituut voor Beeld en Geluid (NIBG), and the historical newspaper database Delpher (Koninklijke Bibliotheek).

16 The intention here is not to study the representation of cities, which would require textual analysis, but to show how media, both as practice and as text, are related to and part of the environment in which they fulfil particular functions.

17 The media archaeological method that is followed here is based on the premise of Hallam \& Roberts, who make an argument for studying city films 'in context,' hence in connection to the environment: "the archaeological trope of 'excavation' is one that connotes a shift towards a fundamentally spatial mode of historiographical engagement." Julia Hallam and Les Roberts, "Mapping, Memory and the City: Archives, Databases and Film Historiography," European Journal of Cultural Studies, 14, 3, 2011, 355-372, p. 364. 
bombed Rotterdam. About 900 people died, 78,700 people became homeless and more than 11,000 premises were destroyed, in essence the entire city centre. ${ }^{18}$ The Germans were well prepared to document the event on film, recording the air raid, the fire, and the resulting destroyed city. There are no images of struggle, victims, or people seeking refuge. It is merely shown as an act of planning. The recordings were used for the Wochenschau, and especially for a propaganda film, Angriff auf Rotterdam (1940, UFA), ${ }^{19}$ to explain the occupation of the Netherlands to the Germans. As such, the images concerned Rotterdam, but they fulfilled functions external to it. Moreover, this UFA production did not mention any authors, since it was not about the work of individual people but of the larger system of the Nazi government. However, the images were appropriated by the Dutch afterwards in order to understand what had happened and to react to the new situation. These images were first incorporated in the film The Dutch Tradition (1943), made by John Fernhout for the Netherlands Information Bureau in New York. It was shown to the American audience to promote the reliability of the Netherlands as an allied partner. ${ }^{20}$ The footage was thus used for opposite purposes, literally crossing borders and changing aims. Only after the war would the images also more directly fulfil functions within the city itself, as I will demonstrate below.

On the $18^{\text {th }}$ of May 1940 , a few days after the bombardment, the city's sitting mayor and aldermen commissioned city planner Willem Witteveen to draw a reconstruction plan. ${ }^{21}$ Mayor P.J. Oud still desired to maintain and restore certain structures, but the supervision of the reconstruction was soon delegated to the national government in The Hague. This emphasizes once more, now through its negation of autonomy due to its destruction, the relationship between the city as a system in connection to the environment. Dutch state planner Johannes Ringers was placed in charge, and while he remained relatively independent from the German administration until 1943, when he got arrested, he supported the idea to rebuild the city from scratch. Moreover, before the war, various plans had been made to modernize the city, which could finally be carried out. The resulting tabula rasa became the precondition for building a new city.

Empty space became empty time. The city had to reinvent itself. This requires not only a memory function but also a capacity to look into the future, and here I want to refer to one of the last works by Niklas Luhmann, in which he makes a distinction between 'memory' and 'oscillation. ${ }^{22}$ Oscillation is the capacity to move beyond an existing situation, by oscillating between established categories, to create space for something new.

To be able to separate memory and oscillation, the system constructs time, that is, a difference of past and future states, by which the past becomes the realm of memory and the future the realm of oscillation. This distinction is an evolutionary universal. It is actualized by every operation of the system and thus gives time the appearance of a dimension of the 'world'. And if there are sufficient cultural guarantees for conceptualizing time, the distinction of time re-enters itself with the effect that past and future presents, too, have their own temporal horizons, their own pasts and futures. ${ }^{23}$

In a hypothetical situation of complete emptiness, there is no difference between past and future. Once movement takes place, traces are left, which become means to distinguish between points in space where one has already acted, and still has to act. In the case of Rotterdam however, there was still a memory of the city that had existed before the bombardment.

In this perspective, the architecture historians of Crimson have raised a fundamental question: what is a city like when it is no longer there ${ }^{24}$ The economist Sergio Conti explains that the 'identity' of a social system is related to its

18 Hans van der Pauw, Rotterdam in de Tweede Wereldoorlog, Boom, 2006, p. 854.

19 Angriff auf Rotterdam, 18', 35mm, b-w, prod.: UFA, coll.: NIBG: RVD 02-0733-01/02.

20 The Dutch Tradition, 1943, 10', 35mm, b-w, dir.: John Fernhout, prod.: the National Film Board of Canada, for: N.I.B., coll.: NIBG: id: 1820. Details about its production history are not available; how the footage was brought overseas could be further investigated.

21 Cor Wagenaar, Welvaartsstad in wording: De wederopbouw van Rotterdam 1940-1952, NAi, 1992, 137; Paul van de Laar, Stad van Formaat: Geschiedenis van Rotterdam in de negentiende en twintigste eeuw, Waanders, 2000, 301.

22 Niklas Luhmann, “Globalization or World Society: How to Conceive of Modern Society?" International Review of Sociology, 7, 1, March 1997, 67-79.

23 Ibid.

24 Crimson, Architectural Historians (Wouter Vanstiphout et al.), "Emptiness," Too Blessed to be Depressed; Crimson Architectural Historians, 1994 2002, 010 Publishers, 2002, 33-52. 
'organization', which is an "ensemble of relations," and positions it against structure, which consists of "material and historic qualities." Conti says that the structure changes more rapidly than the organization. ${ }^{25}$ The structure is merely an outcome. When a city is in disorder, all cognitive functions are called upon to re-establish its identity. Therefore the reconstruction of Rotterdam was not only a physical but also a rhetorical act of planning. "This goes far beyond simply describing the city in terms of the activities that take place there; it means-and here we touch upon an underestimated aspect in Rotterdam's reconstruction— that the city is filled with stories, with narrative lines and points." ${ }^{26}$ This argument can be extended to film, which is already implied by Crimson: "The surface area of Rotterdam had no shape and no content. It presented a screen for all projections of a still imaginary Rotterdam...." ${ }^{27}$ In fact, this happened also literally, with filmmakers recording the new situation. Among them were the operators of Polygoon, a major Dutch film and newsreel company. They made extensive recordings, but only a small amount of the footage was actually used for newsreels. Most was shot for future purposes; the film images became themselves future projections, as I will argue in the next sections.

City planner Witteveen's approach was modestly modern, still relying on boulevards and perimeter blocks. In 1944 he was replaced by Cornelis van Traa, due to strategic manoeuvres - in times of occupation — by the Club Rotterdam, a group of enlightened industrialists that resisted German interference and traditional planning models. Instead, it

supported the ideas of Opbouw, an association of modern architects and planners. A new, radically modern plan was developed, which enabled unhindered traffic circulation, while creating a separate pedestrian shopping area,

concentrated business accommodations, and high-rise housing surrounded by open spaces. In March 1946, Van Traa's so-called 'Basisplan' for the reconstruction was presented..$^{28}$ Replacing existing structures and rejecting conventional planning models, this plan, according to Crimson, cultivated openness. Before WWII, more than half of the city centre's surface had been built on; in the new plan it would be reduced to less than one third. Further, housing would be reduced in the city centre. As a consequence, this also implied the construction of new suburbs. Most importantly, in terms of planning, and also as a democratic process, a gradual elaboration of the plan took place. ${ }^{29}$ Instead of drawing a final image, the plan left space open for future development.

In direct connection to the development of the plan, the municipality opened the Office for Information and Publicity (Bureau Voorlichting en Publiciteit). Among its key tasks were promotion of the city through different media, providing information about its plans, and archiving publications for internal use. ${ }^{30}$ It initiated various media productions and many newsreels were the result of its campaigns. These media documented the 'traces,' in order to remember what had been done and to articulate what had to be done. They served short-term feedback loops, informing the people about events and plans. At the same time, long-term feedback loops emerged, as history was created, first of all by the invention of a tradition, in 1947, with the organization of the festive Opbouwdag ('construction day'), on the $18^{\text {th }}$ of May. It celebrated the day, in 1940, that Witteveen had been commissioned to draw a plan. The highlight of the first Opbouwdag was the opening of an exhibition at Museum Boymans, Rotterdam Straks ('Rotterdam Soon').

While the exhibition was directed towards the future, its motto was a line from a poem by Joost van den Vondel from 1620 , on the destruction of Jerusalem in 586 BC and its subsequent reconstruction.

After crying a stream of pearls, and after his heart has died from mourning, the observer returns to himself, and joy releases his soul, when he sees the rising peaks and the splendid vaults of the new divine buildings. ${ }^{31}$

25 Conti, 2005, p. 35.

26 Crimson, 2002, p. 43.

27 Ibid., p. 44.

28 Adviesbureau Stadsplan Rotterdam, Het Nieuwe Hart van Rotterdam: Toelichting op het Basisplan voor den herbouw van de binnenstad van Rotterdam, Nijgh \& Van Ditmar, 1946.

29 Crimson, 2002, p. 41.

30 Fernande Hazewinkel and Ben van der Schaaf, eds., De Stad aan de man gebracht: Vijftig jaar Gemeentevoorlichting in Rotterdam, Voorlichting Bestuursdienst Rotterdam, 1996, p. 35.

31 "Davids Lofzangh van Hiervsalem of een Poetische uytbreydinge over den 122. Psalm," in: Rotterdam Straks, Museum Boymans, May-August 1947, Bureau Voorlichting en Publiciteit, Gemeente Rotterdam, 1947, p. 3. As remarked by a reviewer of this article, the reference to Jerusalem raises the question if the fate of the city's Jewish citizens was part of this exhibition. No documentation has been found as such, so it merely seems to be a rhetorical reference. 
It thus implied a triple imaginary bind to history and suggested a large-scale historical cycle, international in tone and national in pride, as a pretence to create a city of the future. The poem was also to be heard as a voice-over accompanying a short film with images of ruins and new buildings in Rotterdam, made by film production company Polygoon-Profilti. ${ }^{32}$ Being both an imagination of the past and of the future, it was both an act of memory and oscillation, moving between different times. Moreover, this also applies to its production (i.e., its ontogenesis rather than its ontology): Polygoon was based in Haarlem, but its status of national newsreel provider was locally appropriated. At the same time, Polygoon also reported on Opbouwdag in its national news show. ${ }^{33}$ All this was a foretaste of a much bigger film project.

\section{And Still... Rotterdam}

The 1946 reconstruction plan for Rotterdam stemmed from a radically modernist vision, based on CIAM principles (regarding the 'functional city' based on openness and hygiene, efficiency, and the separation of functions to provide optimal conditions for living and working), but it was rhetorically presented as objective and historically self-evident. ${ }^{34}$ This is comparable to the situation in Great Britain. Regarding films on Glasgow, Elizabeth Lebas has remarked that "the purposes they served and the message they conveyed were neither as simple nor as obvious as their departmental or individual sponsors in the Corporation claimed them to be." ${ }^{35}$ According to Gold and Ward, planning in Britain was presented through film as the application of science, as social medicine, as revelation (vision), and as wizardry. ${ }^{36}$ This oscillating view, moving between different registers, can also be recognized in the 45 minute film En toch... Rotterdam (1950). Commissioned by the Office for Information and Publicity, and produced by Polygoon-Profilti, it would become the longest reconstruction film about Rotterdam and the most extensive explanation of its plan, fulfilling the Office's key task of generating support for the Basisplan. En toch... Rotterdam had its premiere at Luxor as the concluding part of Opbouwdag $1950 .{ }^{37}$ It was presented at various occasions afterwards to different audiences, but it was mainly made for citizens of Rotterdam to provide them with a historical framework, which fulfilled a memory function at the service of a future development.

The film's subtitle became "a film suite of newsreels and documentaries from 1925-1950." It suggests a loose collection of realist images, which increased the credibility of the film as a 'document'. As such it belongs to Wees' found footage category of the 'compilation film,' which 'operate[s] on the assumption that there is a direct correspondence between the images and their pro-filmic sources in the real world." ${ }^{38}$ However, rather than a loose collection, the film was carefully scripted and researched by Polygoon-Profilti and Jan Nieuwenhuis, the head of the Office for Information and Publicity, who was in charge of finding the footage, but the authors were purposefully left anonymous. ${ }^{39}$ The film was not intended as an artwork; it had to be an expression of the city itself. This highlights the problem of agency —there was

32 This short film, Rotterdam Straks, has been preserved as a separate reel, under the label of En toch... Rotterdam, coll.: Stadsarchief Rotterdam, BB-0681. Profilti had been an independent company before the war, until it became part of Polygoon. After the war it was officially renamed PolygoonProfilti, but often it was just called Polygoon.

33 Polygoon Neerlandsch Nieuws, 1947, week 23, "Rotterdam straks, Opbouwdag in de Maasstad," 1'35”, 35mm, b-w, coll.: NIBG: id 47137.

34 Wagenaar, 1992, 26; Van de Laar, 2000, 463. For an English summary of the reconstruction development, see: Han Meyer, "The Promise of a New, Modern Society in a New, Modern City-1940 to the present," in Joan Ockman, ed., Out of Ground Zero: Case Studies in Urban Reinvention, Prestel, 2002, 84-97.

35 Elizabeth Lebas, "Glasgow's Progress: The Films of Glasgow Corporation, 1938-1978," Film Studies, 10, 2007, 34-53, p. 35.

36 John Gold and Stephen Ward, "Of plans and Planners: Documentary Film and the Challenge of the Urban Future, 1935-52," in David Clarke, ed., The Cinematic City, Routledge, 1997, 59-82, p. 66.

37 “Ge krijgt deze stad niet klein; 't blijft altijd: En tóch.. Rotterdam",' Het Vrije Volk, 20 May 1950, 5. (Opbouwdag 1950 took place on 19 May). The film would be shown at various occasions afterwards, e.g., at meetings of unions, at the start of excursions of visiting guests, and at special gatherings, such as the screening for the Nederlands Film Instituut; for the latter, see: Adrianus van Domburg, "En toch.. Rotterdam",' De Tijd, 27 January $1951,7$. Most likely, the film was also shown at the exhibition Ahoy', but no information has been found regarding its film programme.

38 William Wees, Recycled Images: The Art and Politics of Found Footage Films, Anthology Film Archives, 1993, p. 36.

39 Its remake (1965) was directed by Nol Bollongino, who already worked for Polygoon by 1950, but it is unclear if he was involved with the first film. 
F. Paalman, Visions of Reconstruction

not one 'director' of the film, but a network of people related to the Club Rotterdam, which had largely been responsible for the city's plans.

The Club Rotterdam, even though it consisted of the city's businessmen and therefore represented just one social stratum, crossed various existing categories. Its agenda was not merely a matter of economics, trade and industry, and not only a matter of rational thinking and statistics, but also spirituality, social welfare, democracy, art, and culture; although it was concerned with modernity and the future, it was highly conscious about the past and the city's humanist tradition. This is reflected by the found footage in the film, which is a retrieval of the city's memory, but in its ontogenesis also an oscillation between different genres, including both professional and amateur recordings, promotional and art films, propaganda and newsreels, without merely blending them into a dazzling mix. By moving back and forth between different times, it constructs a memory of the city, which creates a distinction with the present, in order to propose what needs to be done.

The film starts with Erasmus and a library, to show that the city acknowledges its humanist history. Important public spaces from before WWII are recalled (Stills Figures 1-3), through amateur recordings and especially images from Andor von Barsy's feature length documentary The City That Never Rests (1928) (Clip 1). ${ }^{40}$ The latter had been made for the municipality, mainly to attract (outside) investors. As argued by Eva Hielscher through a close analysis of the film, it presented the city as a metropolis and stressed its leading position as a modern port, but it also emphasized its

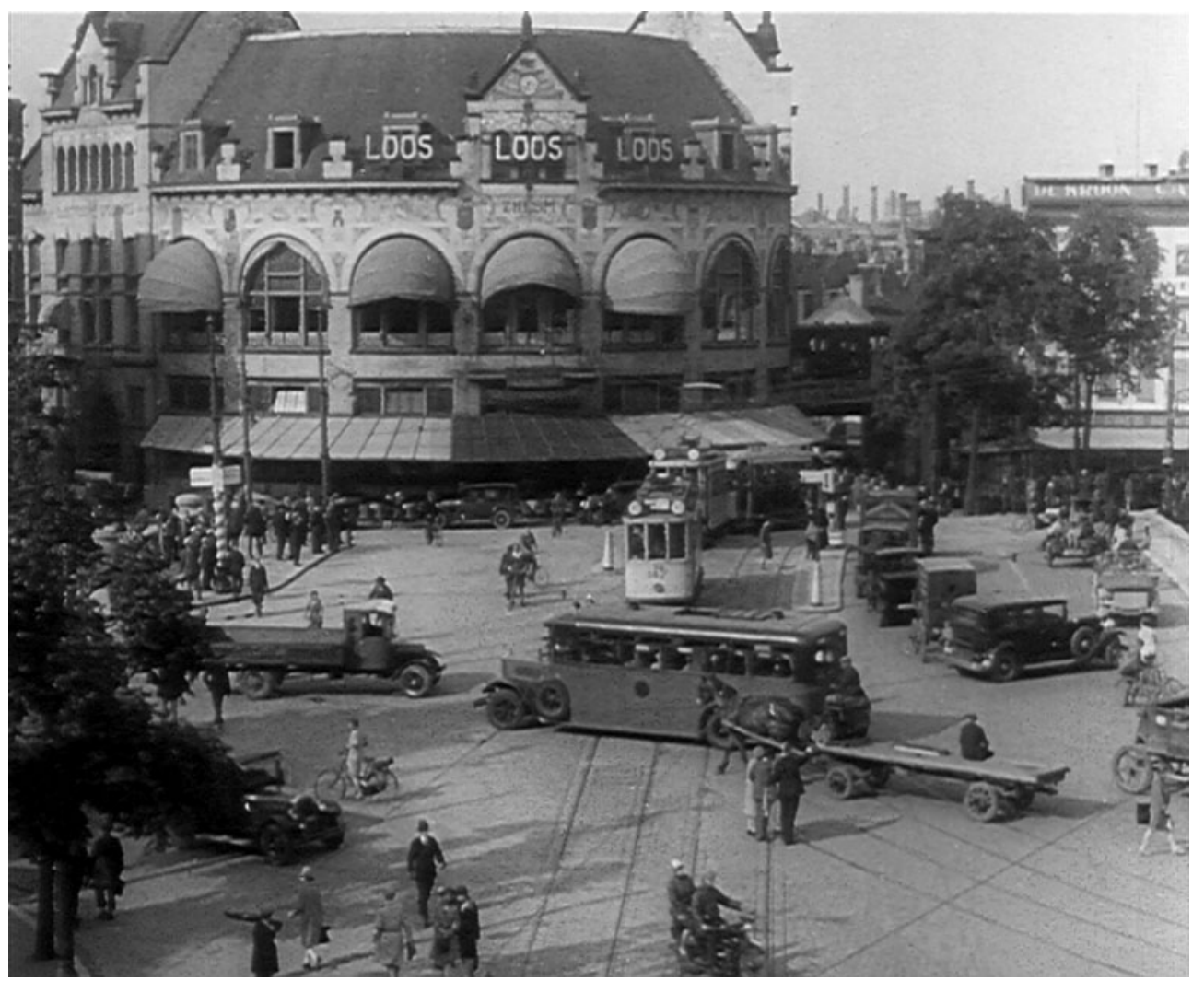

Still 1. From Hofplein (1932), in En toch... Rotterdam (1950). ${ }^{41}$

40 De stad die nooit rust / The City That Never Rests, 1772m (65' original length), 35mm, b-w, mute, dir. Friedrich von Maydell, cam.: Andor von Barsy, prod.: Transfilma, for: Gemeente Rotterdam, coll.: Eye, Stadsarchief Rotterdam, BB-0928 (restored version 2011).

41 Hofplein, 1932, amateur, 7‘, 16mm, b-w, mute, dir. K.L.A. \& R. van der Leeuw, Stadsarchief Rotterdam: BB-3969. 


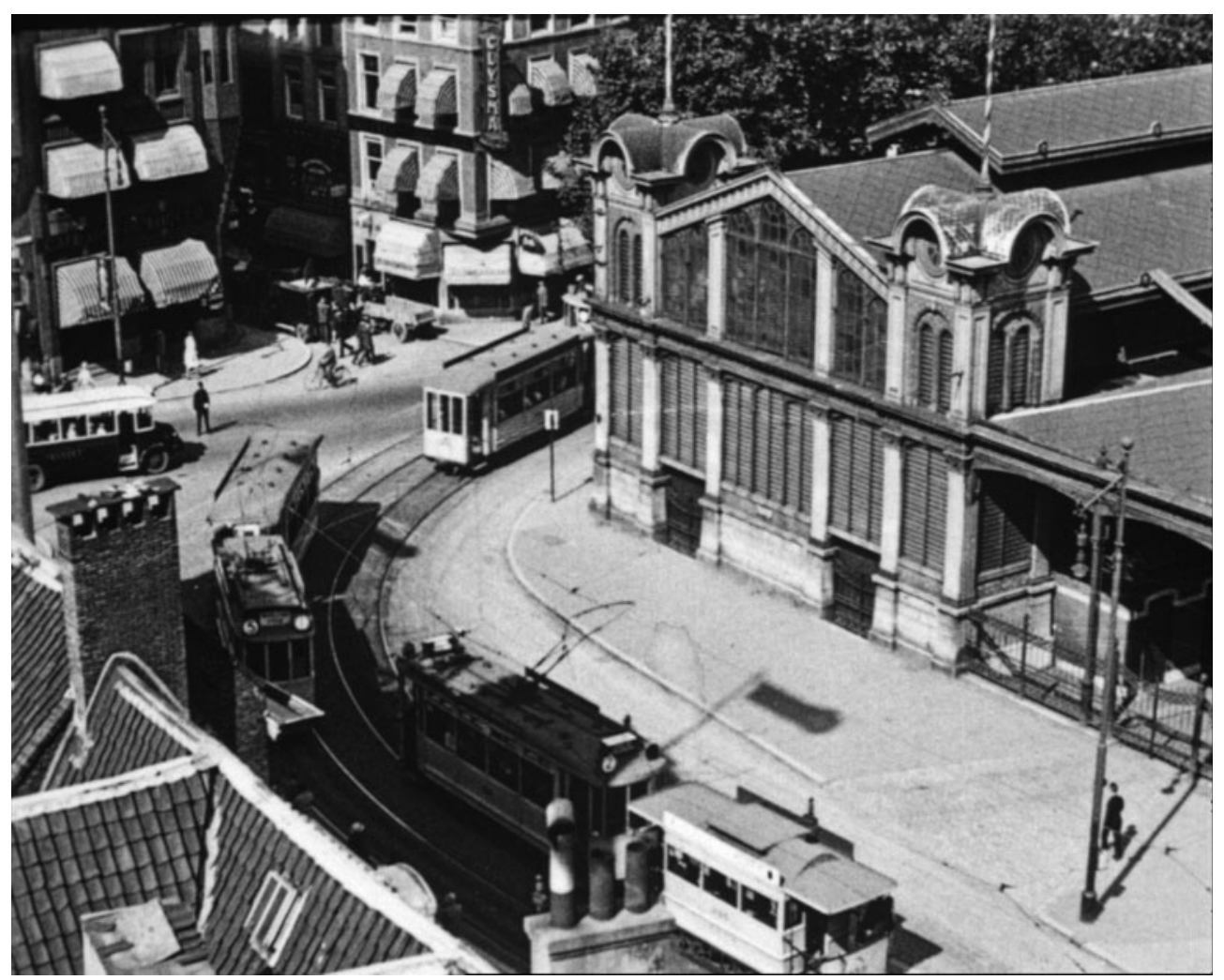

Still 2. From The City That Never Rests (1928), in En toch... Rotterdam (1950).

small-scale, pre-modern features as particular qualities. ${ }^{42}$ This created an ambiguous image. However, because of its promotional purpose, only the images of the port and industry were kept in the recut versions that soon came to replace the original version. By 1938, all of it had lost promotional value, due to rapid changes in the port, and the material was handed over to the Rijks Historisch Filmarchief in The Hague. ${ }^{43}$ After the war, especially the city images especially had gained historical value, and they were retrieved from the national archive. The city, as a system, recollected its own memory, thereby activating its own cinematic cognition, and by doing so, it created a distinction between itself and the state, on which it had depended in previous years.

Video 1. The City That Never Rests, collection Eye. Go to the Go to the online version of this article to watch it. to watch it.

Related in terms of production, but preserved by De Uitkijk in Amsterdam, was Von Barsy's avant-garde short Hoogstraat (1929), about Rotterdam's main shopping street. ${ }^{44}$ It articulates the city's modernity, not through signs of progress, but rather through movements and (social) contrasts, in a self-reflexive mode that highlights vision (Clip 2; Still Figure 3).

Video 2. Hoogstraat (1929, Andor von Barsy), collection Eye. Go to the online version of this article to watch it.

42 Eva Hielscher, "Symphonic Rotterdam or the Flowing City: Von Barsy's and Von Maydell's "The City that Never Rests",' Eselsohren: Journal of History of Art, Architecture and Urbanism, 2: 1-2, 2014, 159-181.

43 An agreement from 1928 obliged the municipality to provide the negatives of municipal films to the Nederlandsch Centraal Filmarchief in The Hague, the precursor of the Rijks Historisch Filmarchief (hosted by the Algemeen Rijksarchief), which would later become part of the Nederlands Filmmuseum (now Eye). The sources used here are to be found in the Stadsarchief Rotterdam, "Gemeentesecretarie Rotterdam afd. Kunstzaken," toegangsnr. 487.01, bestanddeel 6 . It contains copies from the 1950s of a letter by the director of the Havenbedrijf Rotterdam to the Nederlandsch Centraal Filmarchief, 21 November 1938; a letter by the Algemeene Rijksarchivaris to the director of the Havenbedrijf Rotterdam, 28 November 1938; and a letter (mentioning the sent reels) by the director of the Havenbedrijf to the Algemeen Rijksarchief, 9 January 1939.

44 Hoogstraat, 1929, 12', 35mm, b-w, mute, dir.: Andor von Barsy, coll.: Eye, Stadsarchief Rotterdam, BB-3704. 
F. Paalman, Visions of Reconstruction

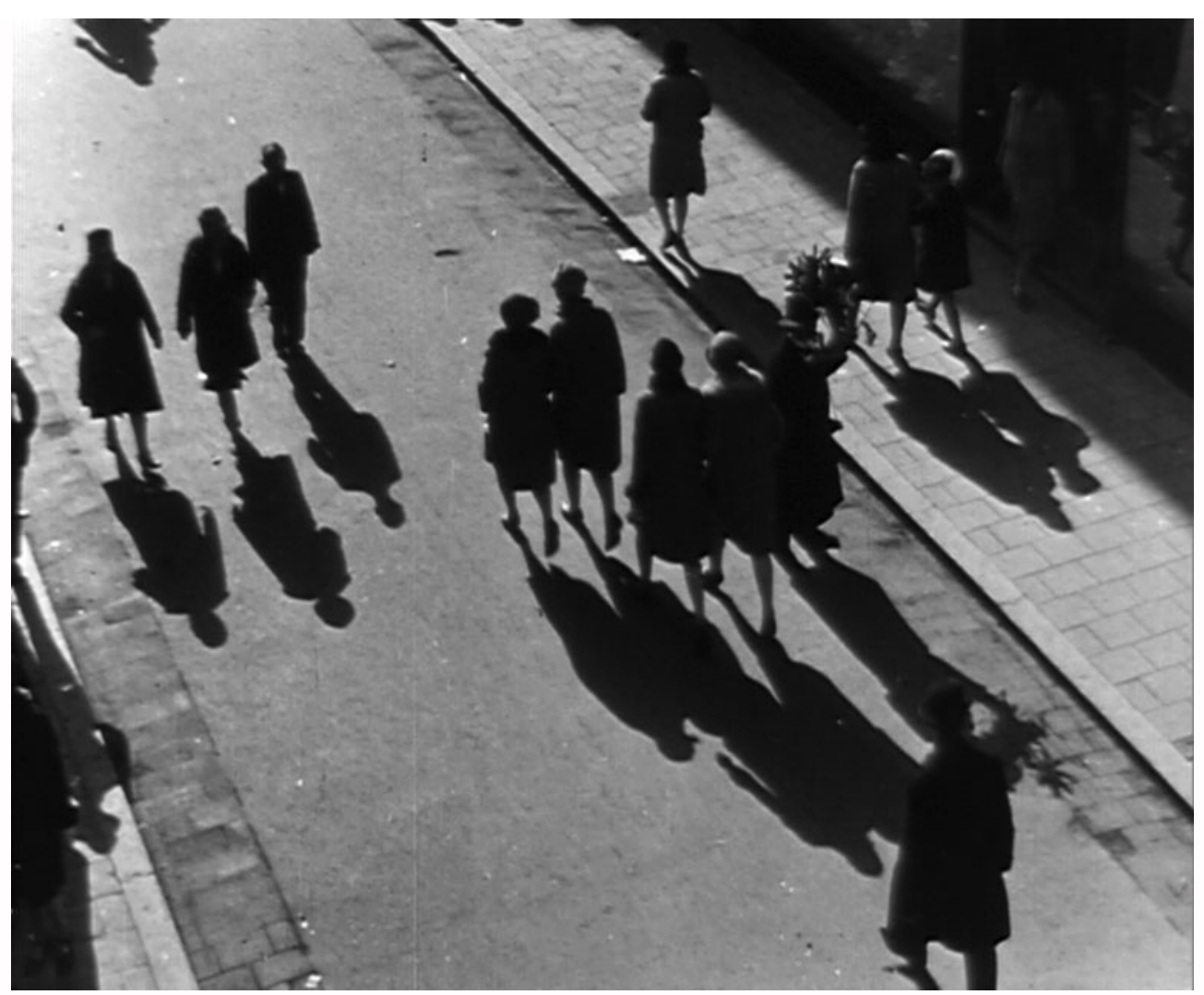

Still 3. From Hoogstraat (1929), in En toch... Rotterdam (1950).

Von Barsy's work was retrieved, and reused-merely as traces of the old city, first of all by Piet Meerburg in his lyrical found footage film Rotterdamse Mijmeringen (see the next section). ${ }^{45}$ En toch... reacted to it, using the same images as well as additional footage from amateur films and newsreels. The narrator of En toch... says that Rotterdam had been a lively city indeed, but it was not beautiful, and just dedicated to labour; moreover, it no longer met modern demands.

In the next act of En toch..., the city is attacked by the Luftwaffe (Still 4; see also Clip 3). En toch... is one of the rare cases in which it is explicitly said that the images were shot by the Germans. The Dutch capitulate, clear the ruins, and commemorate the victims.

The film shows the empty city, the liberation, and the new city planner Cornelis van Traa with his colleagues working on a city that meets modern demands (Still 5). Its modernity is emphasized by its port, business accommodations, and a theatre built from the ruins. However, as alderman and architect Kraaijvanger explains in the film, only our grandchildren will enjoy the results and realize what has been achieved. A new temporal horizon was drawn.

Of ontological interest is the film's emphasis on the role of the Club Rotterdam-especially Kees van der Leeuw, director of the Van Nelle factory where secret meetings took place. Such a meeting is shown, with images of Van der Leeuw, state planner Ringers, his colleague Mouton, and city planner Van Traa, discussing the plans in the factory's boardroom (Still 6).

Unlike what the film suggests, these recordings were not taken during the war but afterwards, in June 1945. Yet, this meeting was no reenactment but simply a continuation of the practice during the war. Most remarkable, however, is the 


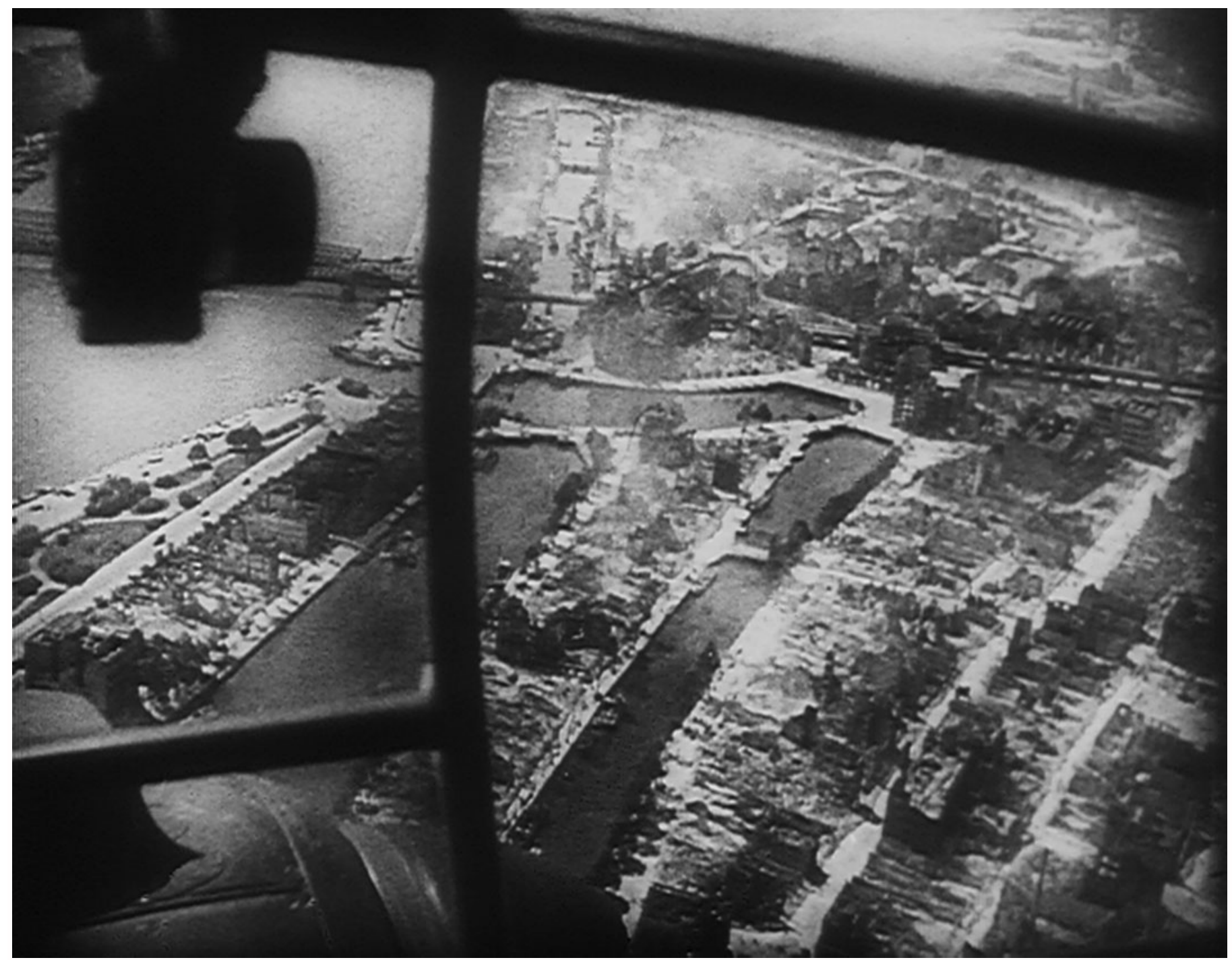

Still 4. From Angriff auf Rotterdam (1940), in En toch... Rotterdam (1950).

fact that these recordings were made before the establishment of the Office for Information and Publicity, which would commission the film. For many years, Polygoon—from outside Rotterdam—had made films for the state but also for the municipality and industry. These commissioning bodies and their representatives, who otherwise remained off-screen, were now seen in the film itself. This points to an ontological collapse of the conditions of the film production into its actual content, almost erasing the threshold of film itself as indicated by Hagener and Elsaesser. Moreover, it shows that Polygoon was intrinsically part of this network. Polygoon either received a commission by these representatives, or it anticipated this, due to the strong ties it maintained and its substantial track record. In fact, most of the 'found footage' had actually been shot for this anticipated commission since 1940. Polygoon had made extensive recordings of the removal of the rubble and early reconstruction works (Still 7). Some images had been used for newsreels, but this was concomitant. It was purposefully-made 'archival material for the future'. Polygoon drew its own temporal horizon in which a future present would be in need of a past.

En toch... nuances Wees' category of the compilation film, based on Leyda's (normative) idea that "the spectator is compelled to look at familiar shots as if he had not seen them before." ${ }^{46}$ Polygoon's own term, film suite, more 


\section{VIEU}

F. Paalman, Visions of Reconstruction

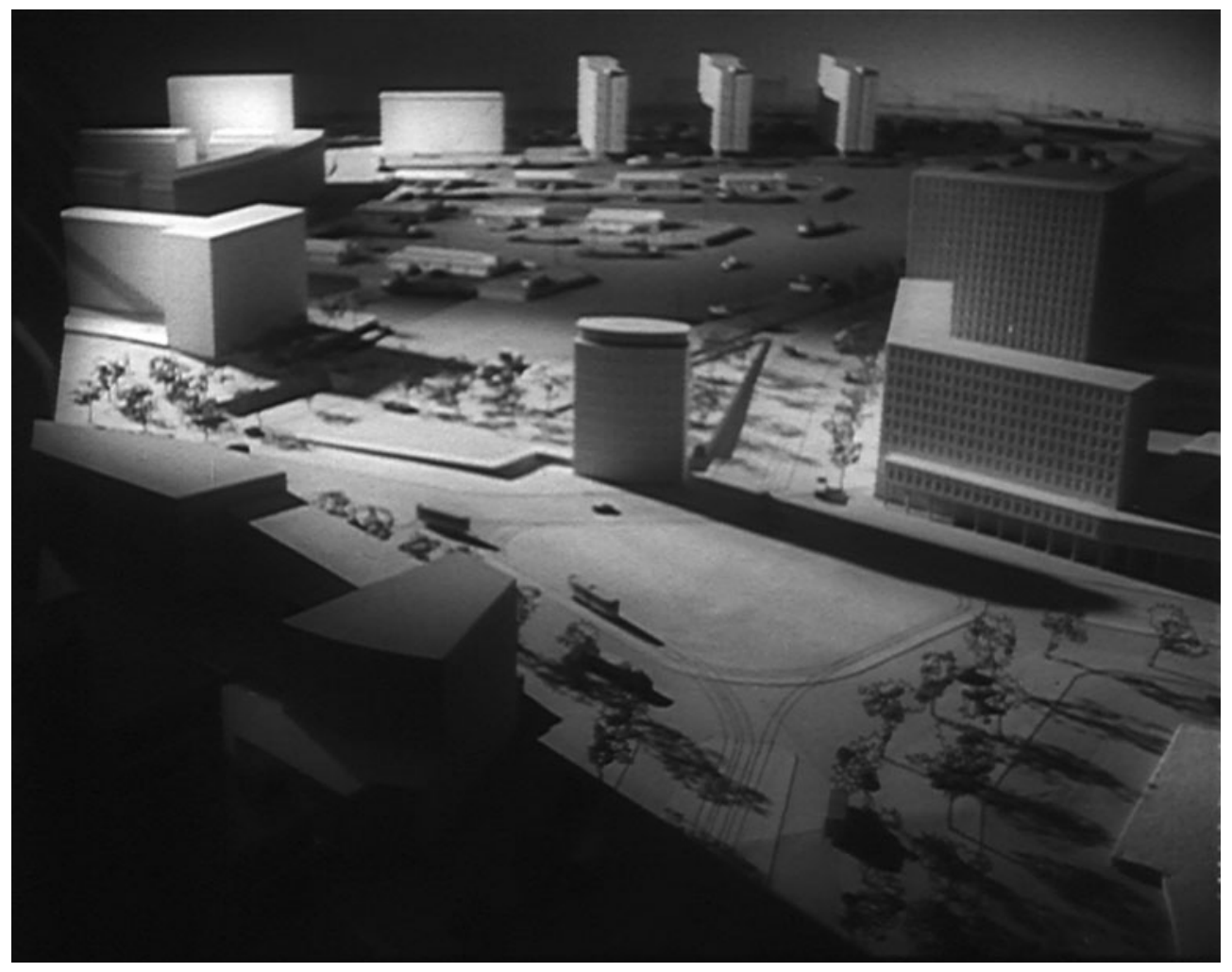

Still 5. Model for the new city, in En toch... Rotterdam (1950).

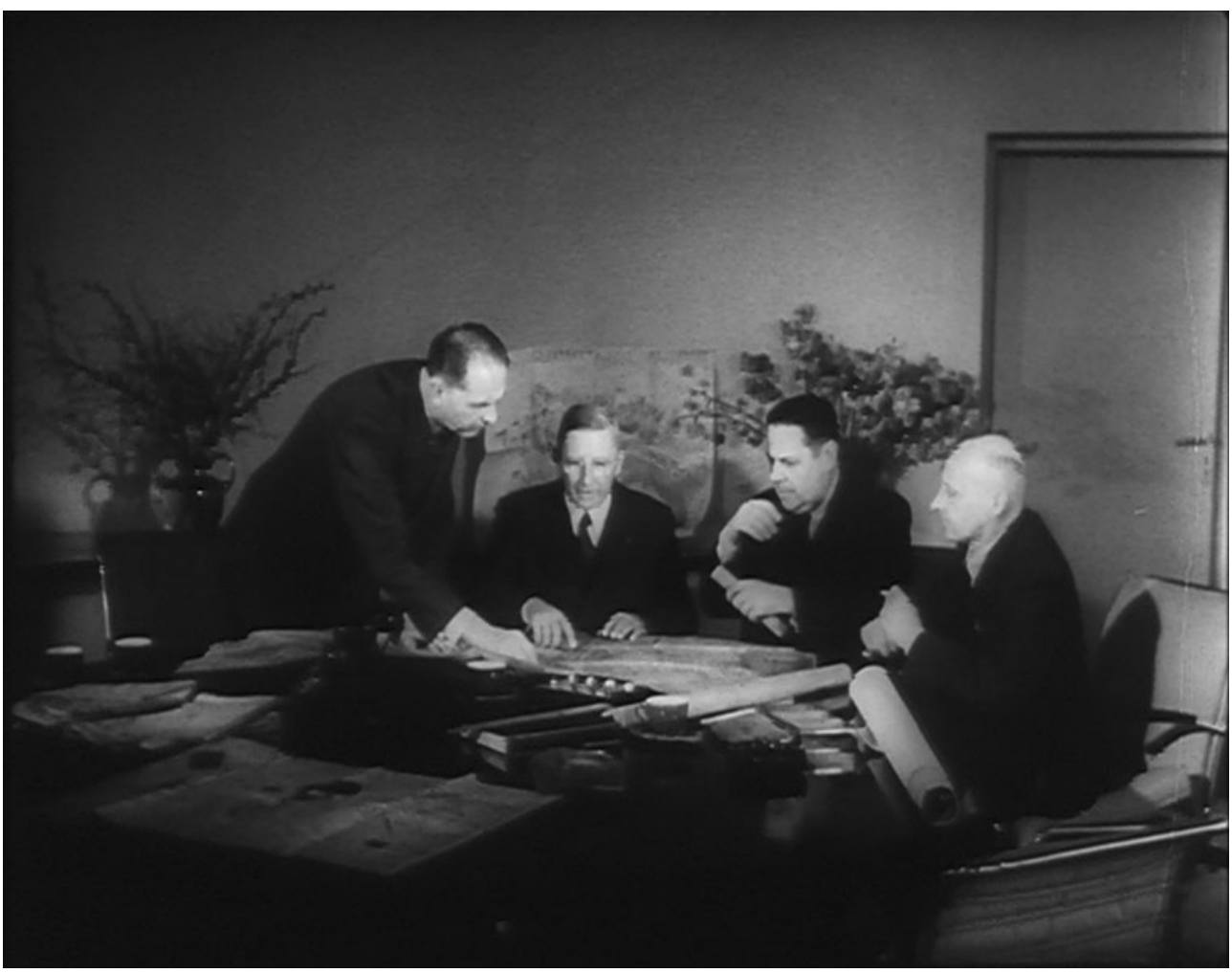

Still 6. Van der Leeuw, Ringers, Van Traa, Mouton in the Van Nelle factory (1945), in En toch... Rotterdam (1950) 


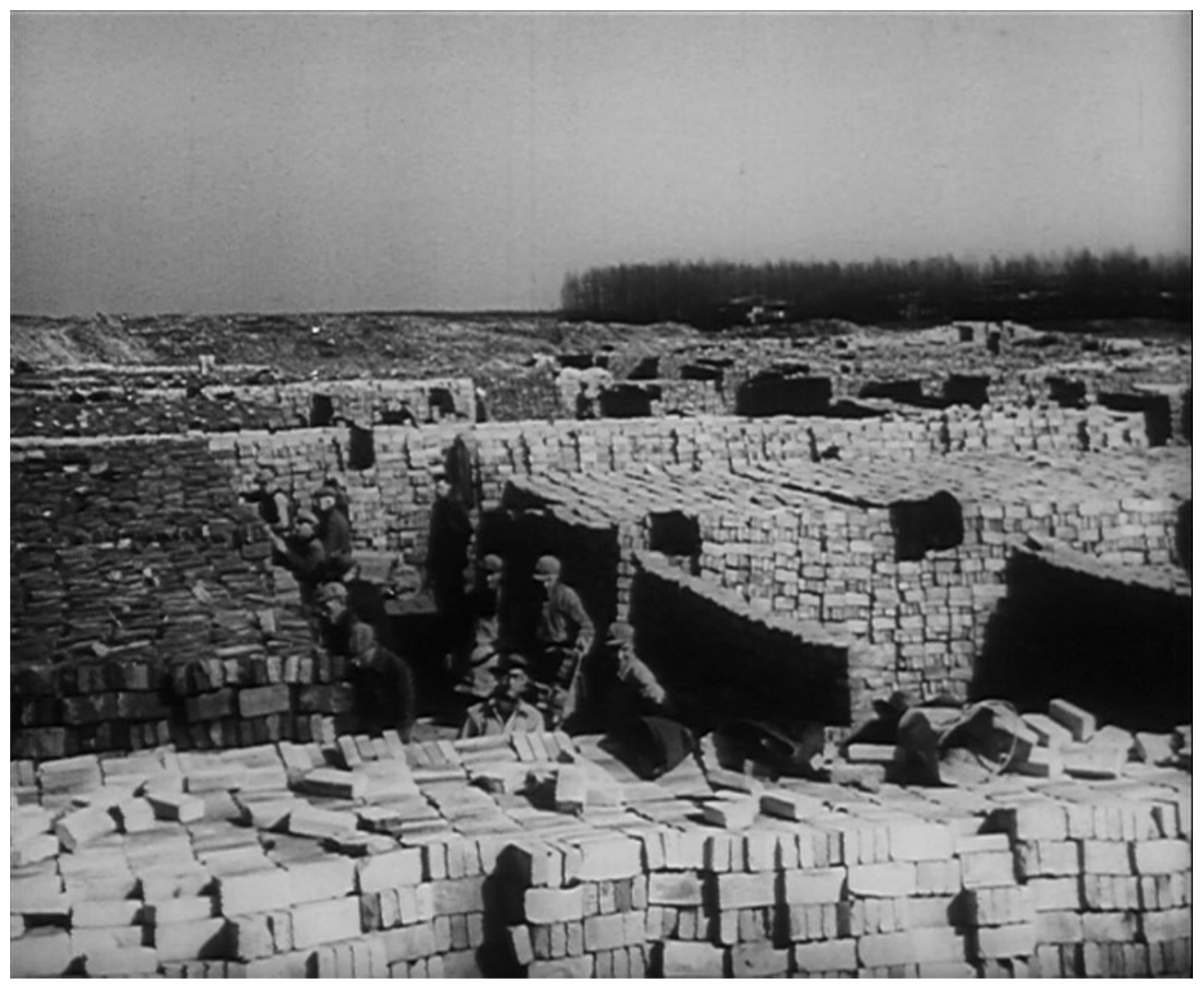

Still 7. Recycling of bricks (1940), in En toch... Rotterdam (1950).

accurately describes a series of related 'acts'. Different from compilation films in which images 'migrate' to a different context, ${ }^{47}$ within the city the audience is still able to directly relate the images to one's own memories, observations, and expectations. That means that distinctions are made between the moving images and the world outside, or what is made explicit and left implicit. This can be further elaborated through Eskjær's discussion of the relationship between film and reality. "Making observations always implies a distinction (e.g., new/old) to mark what is at the center of the observation (e.g., new) and what is external to the observation (old), even though the external is still an essential part of the observation." 48 In Eskjær's example, 'old' is the blind spot, and the blind spot can only become visible by drawing a new distinction. To that end, historical footage was used in En toch... This, however, creates another blind spot, which can eventually be resolved when the observer is observed, or through self-observation. The 'ontological collapse' brings this about: those who monitor and direct the system come into the picture but also-indirectly-the film production company (this is already implied by the 'observer' in Vondel's poem that reads as the 'prologue' of the film). However, as Eskjær explains, observing the observer, whether or not this is self-observation, creates another blind spot. "Each observation creates a new blind spot, which is only observable from a new observation point building on a new distinction, which also remains invisible, and so on." 49 For the system to monitor this, it would be necessary to expand its cognitive apparatus and to take an even broader view beyond the single film that already includes various films. 
F. Paalman, Visions of Reconstruction

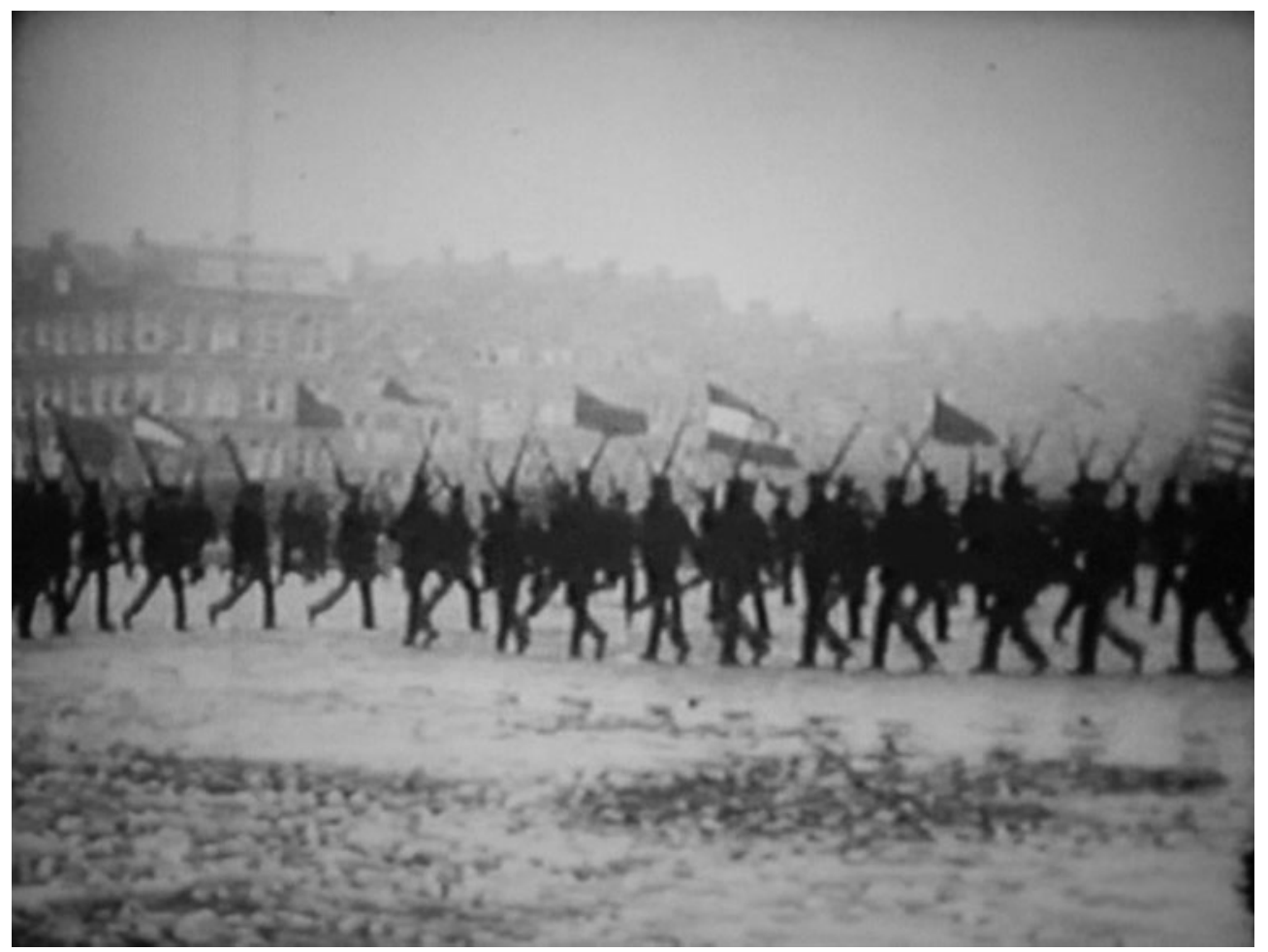

Still 8. From 250-jarig bestaan Korps Mariniers (1925, Orion), in Rotterdamse Mijmeringen (1948/1953).

\section{From a City Film as Archive...}

The Luxor theatre, where En Toch... had its premiere, had miraculously survived the war, to become municipal property. For a part of its programming, the municipally sponsored RKS (Rotterdam Arts Council) invited Piet Meerburg. ${ }^{50}$ Shortly after the war, Meerburg had founded cinema Kriterion in Amsterdam, and together with Paul Kijzer and David van Staveren, the Nederlands Historisch Filmarchief (later Nederlands Filmmuseum, now Eye). ${ }^{51}$ The RKS also asked Meerburg to make a compilation film, Rotterdamse mijmeringen ('Rotterdam Musings'). ${ }^{52}$ This version has not been preserved, but an advertisement from 1948 mentions that it contains images of the visit by the queen in 1915, the celebration of the $250^{\text {th }}$ anniversary of the Navy in 1925 (Still 8), and from The City That Never Rests from 1928, all found in the Rijks Historisch Filmarchief in The Hague, next to images from Hoogstraat. ${ }^{53}$ Since it was partly the same material as in En toch..., which would be released later but was already in production prior to Rotterdamse mijmeringen, it seems that some sort of interference occurred between the two film productions. Moreover, film scholar Eva Hielscher, in her research on the archival history of the city symphony, ${ }^{54}$ has discovered that Hoogstraat was among the first films of the Nederlands Historisch Filmarchief. Its recycling in the two films suggests once more that Meerburg occupied indeed a pivotal position, which reflects the convoluted history of the emerging film archives at both the national and local level, with each of them fulfilling particular purposes based on a differentiation of cognition.

50 Annemieke Hendriks, De pioniers: Interviews met 14 wegbereiders van de Nederlandse cinema, International Theatre \& Film Books, $2006,76$. Henk Berg, Over Stalles en Parket, Rotterdam en het WitteDoek, Ad. Donker, 1996, p. 166.

51 Hans Schoots, 'Zestig jaar Filmmuseum: Grote Sprong over het water,' De Filmkrant, 281, October 2006, 8 May 2015.

52 "Rotterdamse Mijmeringen," Het Vrije Volk, 28 August 1948, 9. In this report a co-author is mentioned, just by his surname, Kijzer. It might be Paul Kijzer, co-founder of the Nederlands Historisch Filmarchief.

53 "Rotterdamse Mijmeringen," Het Vrije Volk, 28 August 1948, 9. "Filmprogramma's voor de volgende week," Het Vrije Volk (advertisement), 26 August 1948, 4. The advertisement does not mention The City That Never Rests, but Zo was eens Rotterdam, which is a later, shortened version of this film.

54 Personal communication, 2014; this is part of her yet unpublished dissertation project at Ghent University. 


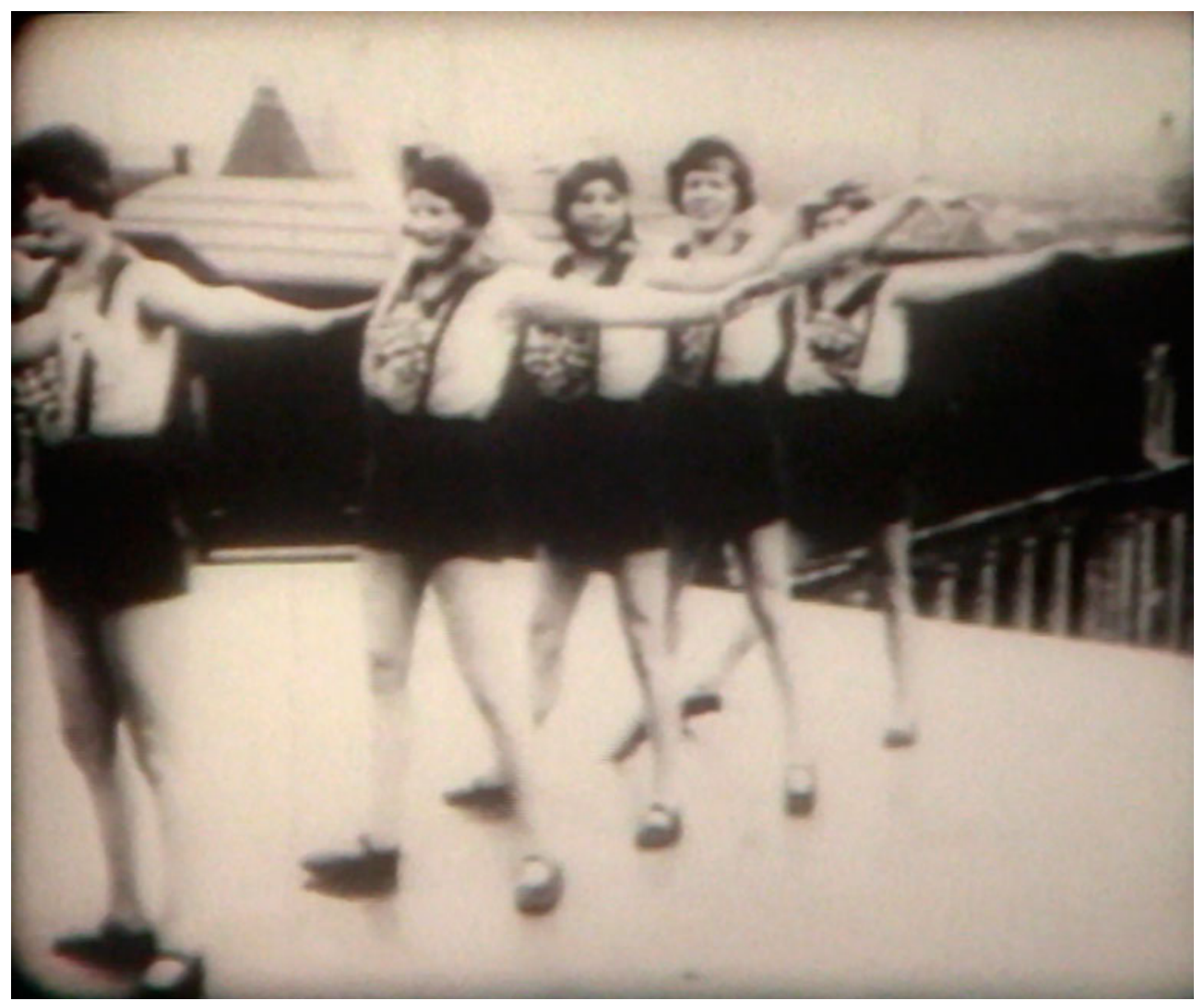

Still 9. Gymnasts on a roof at Coolsingel (anonymous, 1920s), in Rotterdamse Mijmeringen (1953).

Rotterdamse mijmeringen was released in August 1948, and for three weeks it ran as a short in Luxor, accompanied with live organ music by Henk Breton. ${ }^{55}$ Due to its popularity, it was frequently reshown after this and probably changed several times. ${ }^{56}$ Does it mean it was actually an 'archival project in process'? In 1953, a completely new, 20 minute version was made by Piet Meerburg in collaboration with performing artist Alex de Haas, who included the film in his cabaret programme "Salon des Variétés," performed at Luxor. ${ }^{57}$ Afterward it was still frequently shown, sometimes also with live commentary by De Haas. This context shows that the film constructed a memory, as part of an artistic act, which simultaneously served the function of oscillation, moving between different urban realms and periods. Moreover, as it self-consciously referred to the days of early film (variété), brought to the post-war days of progress, it presented its audience a clear distinction, contrary to the filmic text itself in which different times intermingled.

For the 1953 version, Meerburg had more footage at his disposal, including Polygoon newsreels and amateur recordings, some of which had already appeared in En toch... (e.g., Still 1). The film starts and ends with images of the reconstruction. In between it shows urban culture and popular places before the war (Still 9). This includes images from The City That Never Rests and Hoogstraat, which are, in the first half of the film, loosely interchanged with the UFA material of the attack. The overall image of Rotterdam is a mix of cosmopolitan and village life. By showing such contrasts it was modern, but rather than offering an experience of modernity, it attempted to picture an urban identity.

55 "Filmprogramma's voor de volgende week," Het Vrije Volk (advertisement), 2 September $1948,4$.

56 "Filmochtend K.P.C.," Het Vrije Volk, 19 December 1950, 5. The author remarks that "the film remains up to date all the time"-so it seems that the film was regularly changed.

57 O. van der Wal, "Alex de Haas laat verleden herleven," Het Vrije Volk, 2 September 1953, 3. The show took place fourteen times at Luxor. On other occasions, De Haas would also give his live commentary with the film, see e.g., "De Havenvereniging: Twintigste vejaardag gróót feest," Het Vrije Volk, 31 January 1959, 5. The film was also part of the film programme of the exhibition E55 (1955). 
Like the first version, Rotterdamse mijmeringen attracted substantial attention, and even Polygoon—indeed—paid attention to it in its news show. ${ }^{58}$

Meerburg's production became a contemplative 'archive' of the city that had disappeared. As an early Dutch compilation film about the city, different from the earlier collage-like city symphonies with purposefully recorded images, it celebrated the value of historical footage, not so much for a focused evaluation of developments or to construct a historical narrative to determine a particular aim, but merely as an associative spectacle that resonated with both memories and desires of a general local public. Oscillating between different sorts of images, made at different times and sites, it presented an imaginary historical condition, which fuelled the post-war imagination. It promoted a different kind of city than En toch... and other films, especially Steady! (1952, Herman van der Horst). The latter, sponsored by the Marshall Plan in order to show its achievements worldwide, presented an artistic vision of the envisioned city, through images of the harbour as a modern environment and a selection of new buildings and projects under construction. As such, the film represented the city to come, rather than the city's still-existing structures that could be found in parts that had not been destroyed. ${ }^{59}$ However, Rotterdamse mijmeringen and Steady! started to be screened and discussed together, to rethink the reconstruction. ${ }^{60}$ In the imagination, they represented past and future, and as a popular programme they helped to create "sufficient cultural guarantees for conceptualizing time," to refer to Luhmann again, and so this distinction of time re-entered itself. Film provided stimuli for the city's cognitive operations, which would be strengthened in following years.

\section{5 ...to a City Film Archive}

Parallel to the city's physical reconstruction, the city also made attempts to reanimate its culture that were similarly supported by both private initiatives and the municipality. In June 1954, the Mayor and Aldermen established a committee for the policy on the arts (Commissie voor het Kunstbeleid). It consisted of various sections, including one for film. ${ }^{61}$ Among its members were Piet Meerburg and the already mentioned David van Staveren—who had also been involved with setting up film archives. ${ }^{62}$ The section advocated the production of local films and enabling various social and cultural institutions to show quality films by providing advice and equipment and tax incentives. A link was made to institutions that possessed films themselves. ${ }^{63}$ It argued, moreover, that all the films related to Rotterdam, including certain 'neglected' films from state archives, should be collected, catalogued and preserved by a city film archive. This institution could also advise and assist other organizations that wanted to show films. ${ }^{64}$

This proposal for a city film archive was not merely a desire; it was an attempt to direct actual developments, related to the films Rotterdamse mijmeringen and especially En toch... Rotterdam. The material that information officer Nieuwenhuis had collected for the latter film had been handed over to the city archive. ${ }^{65}$ Therefore, under supervision of city archivist Hazewinkel, a depot with a safe had been built on the top floor of the municipal archive. As addressed by Hazewinkel himself, it marked the very beginning of the municipal film archive. The specific form of En toch..., being a

58 Polygoon Neerlandsch Nieuws, 1953, week 4, “Foto's uit de film 'Rotterdamse mijmeringen'," 3’22”, 35mm, b-w, no sound preserved, coll.: NIBG: id 1627. Interestingly, Polygoon has registered this newsreel as a sponsored film.

59 Houen zo! / Steady!, 1952', 21', 35mm, b-w, dir. Herman van der Horst, for: MSA, coll.: NIBG: RVD 07-0400-01.

60 See e.g., "PvdA-afdeling beziet herbouwplannen," Het Vrije Volk, 16 May 1957, 11.

61 A.J. (Dries) van der Vlerk et al., Rapport van de commissie voor het kunstbeleid, uitgebracht aan burgemeester en wethouders van Rotterdam, Gemeente Rotterdam, 1957, 4-5 and 104.

62 Next to the Nederlands Historisch Filmarchief (Amsterdam), Van Staveren had already been involved with the Nederlandsch Centraal Filmarchief (The Hague), since 1919. This was a precursor of the Rijks Historisch Filmarchief (later part of Eye). See also: Eye, "Het Nederlandsch Centraal Filmarchief," 7 May 2015.

63 a.o. Bureau Voorlichting en Publiciteit and the Gemeente Film Archief (related to the former, which included material collected for En toch.. Rotterdam), in: A.J. (Dries) van der Vlerk et al., 1957, p. 105.

64 Ibid. at 105-106, 113-114.

65 Stadsarchief Rotterdam, 297.01, inv. nr. 461, letter by H.C. Hazewinkel to Mayor and Alderman, 25 November 1958 , and an internal letter by the Commissie voor het archief, 29 January 1959. 


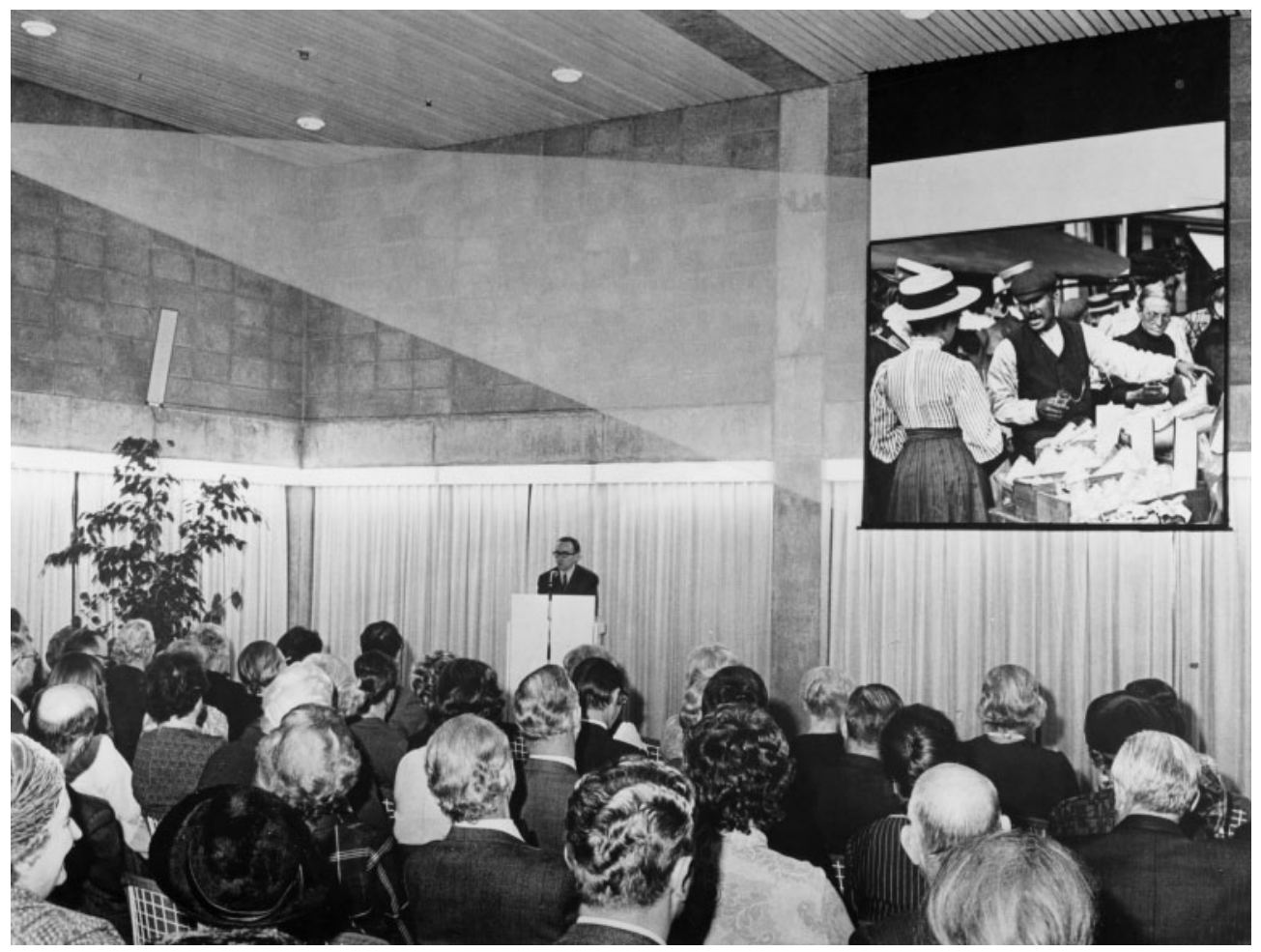

Still 10. Film screening at the city archive, with an introduction by P. Ratsma, 25 November 1971 (photo: Stadarchief Rotterdam).

compilation film, literally resulted in a film collection. Whereas the film had created the city's identity anew, the preservation of the material allowed for a future reconstruction of this creation—of which this text is a testimony.

Since En toch... had made use of footage from Von Barsy's The City That Never Rests (1928), a renewed interest in this film emerged, of which there were only short versions left, along with left over bits and pieces. While the historical value of the cut-out city images had been recognized and used in Rotterdamse Mijmeringen and En toch..., by 1958, the Port Promotion Council (Havenbelangen) also recognized the value of the film as a whole and requested a restoration. This was grist to the mill of city archivist H.C. Hazewinkel, and so he asked the city for a policy on film, or actually, to carry out the plans that the Commissie voor het Kunstbeleid had proposed. Hazewinkel also used the request as an argument to enlarge and improve the facilities for film preservation, to acquire new films, and to ask for extra personnel to run the film archive. ${ }^{66}$ The Mayor and Aldermen agreed. As a result, city archivist H.C. Hazewinkel started to collaborate with the Nederlands Filmmuseum, to preserve The City That Never Rests and related titles, ${ }^{67}$ although a restoration was not yet possible. ${ }^{68}$ Moreover, the city film archive, as part of the general municipal archive, was officially established in $1959 .{ }^{69}$ Hazewinkel subsequently approached various municipal departments, companies, film producers and broadcasters, also abroad, asking for copies of films related to Rotterdam. ${ }^{70}$ Within the broader environments and organizational systems of which it was a part, the city was in search of its memory and cognitive apparatus, reappropriating its images for local purposes.

66 Idem.

67 This film had been transferred from the state archive in The Hague to Amsterdam. The city archive got $16 \mathrm{~mm}$ copies of the preserved material. Stadsarchief Rotterdam, "Gemeentelijke Archiefdienst Rotterdam," Archief van het archief, toegangsnr. 297.01, inv. nr. 461 (1958-1962), dossier "correspondentie filmcollectie," letter by Jan de Vaal, director of the Nederlands Filmmuseum, to Hazewinkel, 2 May 1959.

68 Stadsarchief Rotterdam, 297.01, inv. nr. 461, letter by Hazewinkel to Mayor \& Alderman, after a request by Barendse (Havenbelangen), 25 November 1958. Several attempts were made to restore The City That Never Rests, in the 1980s and 1990s, but it was only accomplished in 2011 , by Simona Monizza (Eye), i.c.w. Stadsarchief Rotterdam and Floris Paalman.

69 Wilma van Giersbergen, "De collecties van de Topografisch-historische Atlas van het Gemeentearchief Rotterdam (GAR)," RKD Bulletin, December 2005, 12. 9 May 2015.

70 Stadsarchief Rotterdam, 297.01, inv. nr. 461, examples are to be found in most of the documents in this file. 
In 1961, Rudolf Renting succeeded Hazewinkel as the city archivist, and he took charge of the film collection. ${ }^{71}$ Soon this municipal film archive counted hundreds, and over the course of years, thousands of titles. Within the city, the archive began to organize film screenings, in collaboration with the historical society Roterodamum (Still 10). At the same time, the archive was also asked to provide footage for programmes on national television and even foreign television stations began to approach the archive.

All this happened long before the 'archival renaissance' that generated a conservationist love for home movies, industrial films, educational films and other "dogs that did not bark," as Thomas Elsaesser has observed. ${ }^{72}$ In fact, not only its films, but the municipal film archive itself, with its variety of moving images made for different purposes and a topographic-historical interest, seems to have been 'a dog that did not bark.'

\section{Town Without a Heart}

By 1964, the Basisplan for the reconstruction had largely been carried out and city planner Van Traa retired. The next year, a large exhibition was organized to celebrate the reconstruction. On that occasion, a remake of En toch... Rotterdam was presented. ${ }^{73}$ The first half of the film still used historical footage, mainly by Von Barsy, but in a condensed way. The second half simply showed the achievements of the reconstruction; it showed a modernist city in optima forma. As such, it would also be the last 'reconstruction film.'

Video 3. En toch... Rotterdam (1965, Polygoon-Profilti), with images of Angriff auf Rotterdam (1940, UFA) - coll. Nederlands Instituut voor Beeld en Geluid. Go to the online version of this article to watch it.

In 1966, on the $14^{\text {th }}$ of May, the anniversary of the bombardment in 1940, Dutch television station NCRV broadcast the 47 minute documentary Stad zonder hart ('Town Without a Heart'), by Jan Schaper, a charismatic personality in the cultural milieu of Rotterdam. This documentary was the first major critical analysis of post-war Rotterdam. Schaper criticizes its premises, arguing that the main problem of the new city centre is the limited number of dwellings; it has become a clinical environment that is empty after rush hour. Only on Saturdays the city is as lively as before WWII, which is illustrated by images from-indeed_En Toch... Rotterdam (1950), which in turn includes shots of Von Barsy's The City That Never Rests and Hoogstraat (Stills 2-3). The old city was characterized by intimacy, movement, and all walks of life. The new city was straight and lacked the human scale with its new high-rise offices (Still 11). Schaper advocated a city in which the people are central. It needed an 'urban fabric' that allows for opposed movements, in which individuals can find their own ways. Schaper included collage-like sequences with images of young and old people, interchanging panning and tracking shots of men and women, moving between outside and inside (especially pubs), business and leisure, living and working. After all, however, Schaper especially made a case for the youth to discover itself (Still 12).

Schaper started the production in 1964 without a clear plan. During the 1960s, his Rotterdam based Open Studio collaborated on more than a thousand television productions. Since national television was based in Hilversum in the middle of the country, Schaper's Open Studio was often called upon when shooting had to be done in or near Rotterdam. Whenever there was time left, Schaper or his employees went into the city to make recordings. ${ }^{74}$ This was a common practice, at first to feed the studio's own stock archive, but gradually a more concrete plan emerged. Schaper decided that the modern city had to be compared to the old one and sent a request to the municipal archive. ${ }^{75}$ He got a

71 Van Giersbergen, 2005, 12.

72 Thomas Elsaesser, 'Is Nothing New? Turn-of-the-Century Epistemes in Film History,' in Nicholas Dulac et al., eds., A Companion to Early Cinema, Blackwell, 2012, 587-609, pp. 597-599.

73 En toch... Rotterdam: Documentair verhaal van een stad gesterkt door strijd, 1965, 26', 35mm, b-w, commentary: Philip Bloemendal, script: Bollongino, prod.: Polygoon-Profilti, for: Bureau Voorlichting en Publiciteit, coll.: NIBG: PR0737 a-f.

74 Camera: Jan Schaper, Ferenc Kalman Gall, Hans Visser; sound: Christine van Roon, Martin van Dalen.

75 Stadsarchief Rotterdam, 297.01, inv. nr. 461, letter by Jan Schaper, 23 November 1965. 


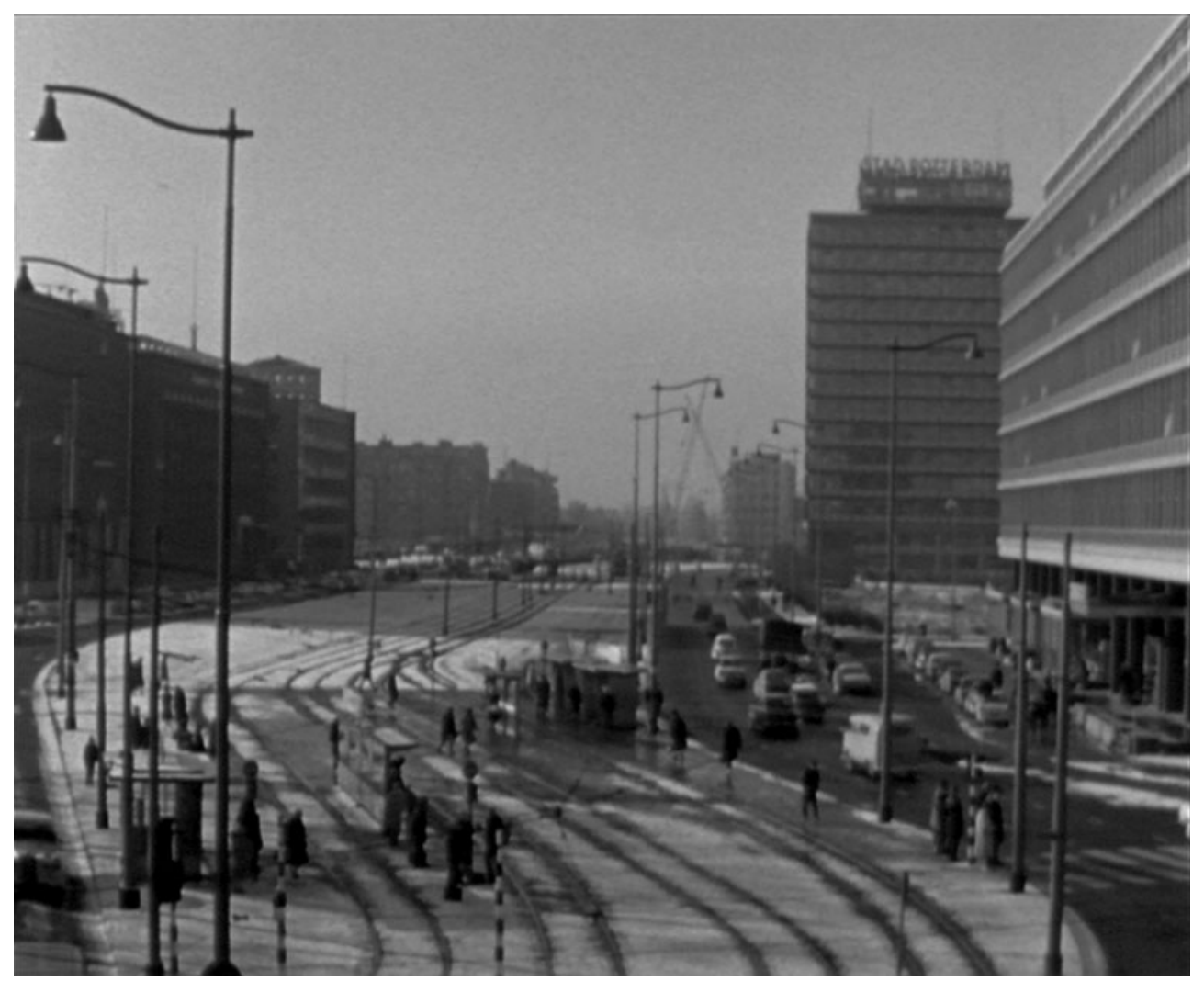

Still 11. Stad zonder hart (1966).

copy of En toch... (1950), from which he took the UFA footage, i.e., the German recordings of the bombardment that had been used in that film and re-appropriated Von Barsy's films (Stills 13-14), even without knowing Von Barsy's original work. Schaper's Stad zonder hart articulated the dynamic of the old city again, while criticizing the modern planning practice of separating spatial functions. Inserting historical footage, literally cut out from a film that had promoted the new city, meant a reappropriation of the city's memory through film. Using the historical footage to match it with the recorded results of the reconstruction, the film provided feedback for the city to move into another direction. Not unlike En toch..., which moved back and forth in time, this documentary was also a matter of oscillation, yet drawing different perspectives.

Stad zonder hart was broadcast on national television, feeding a larger discussion on urban planning and urban renewal in the Netherlands. It is, moreover, a manifestation of Schaper's ideas about the city in general, but since Rotterdam was seen as a major planning model, his argument was also specifically targeted at this city. He was already involved in local discussions, and with this documentary he addressed the city's officials, to make them more aware of human needs. To this end he used his contacts in Hilversum to give a platform to his views; being broadcast on national television, the documentary gained weight and urgency that could not be ignored. Rather than Rotterdam being an autonomous urban system, it functioned within the country, and it made use of this exchange. Broadcasting the documentary was especially important for the city itself, as it triggered a serious discussion within the municipality. ${ }^{76}$ To facilitate this discussion, broadcasting station NCRV asked Schaper to make a report that also included interviews with 


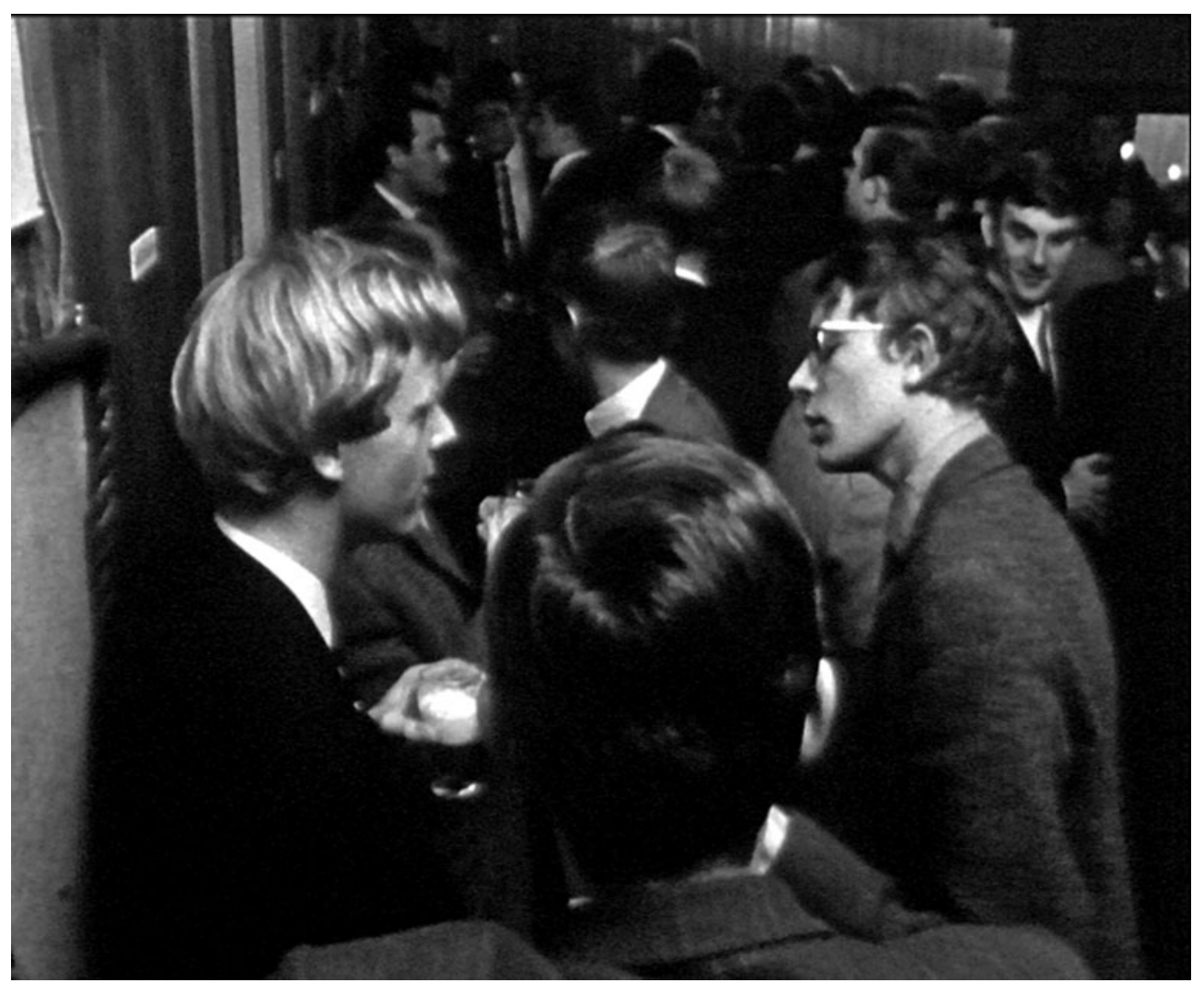

Still 12. Stad zonder hart (1966).

officials. ${ }^{77}$ It propelled the critical discourse. Schaper subsequently worked on a sequel to his film but did not finish this project. However, the discourse had already been changed, and the city's development course would be adjustedtowards Schaper's parameters of social interaction. As such, his work, which itself moved back and forth between film and television, also oscillated between different social and spatial categories and between different times. This helped the city as a system to adjust to new conditions, not just external, but especially internal conditions.

To enable both the promotion and criticism of the modern city, the municipal archive played an active role. This would continue when video came to the fore in the 1970s and local television in the 1980s. The archive's function would be reinforced in the next decades. ${ }^{78}$

\section{Conclusion}

After World War II, films accompanied the reconstruction of Europe's destroyed cities. Many of them made use of historical footage. This study has been an attempt to find out where the footage came from and whether it was the beginning of the 'municipal film archive.' This has subsequently raised a theoretical question regarding the functions of (municipal archives of) moving images dealing with the city. Through the case of Rotterdam, I have argued that both film and television, seen from a local perspective, have been part of an adaptive system in which they have fulfilled collective cognitive functions. 
F. Paalman, Visions of Reconstruction

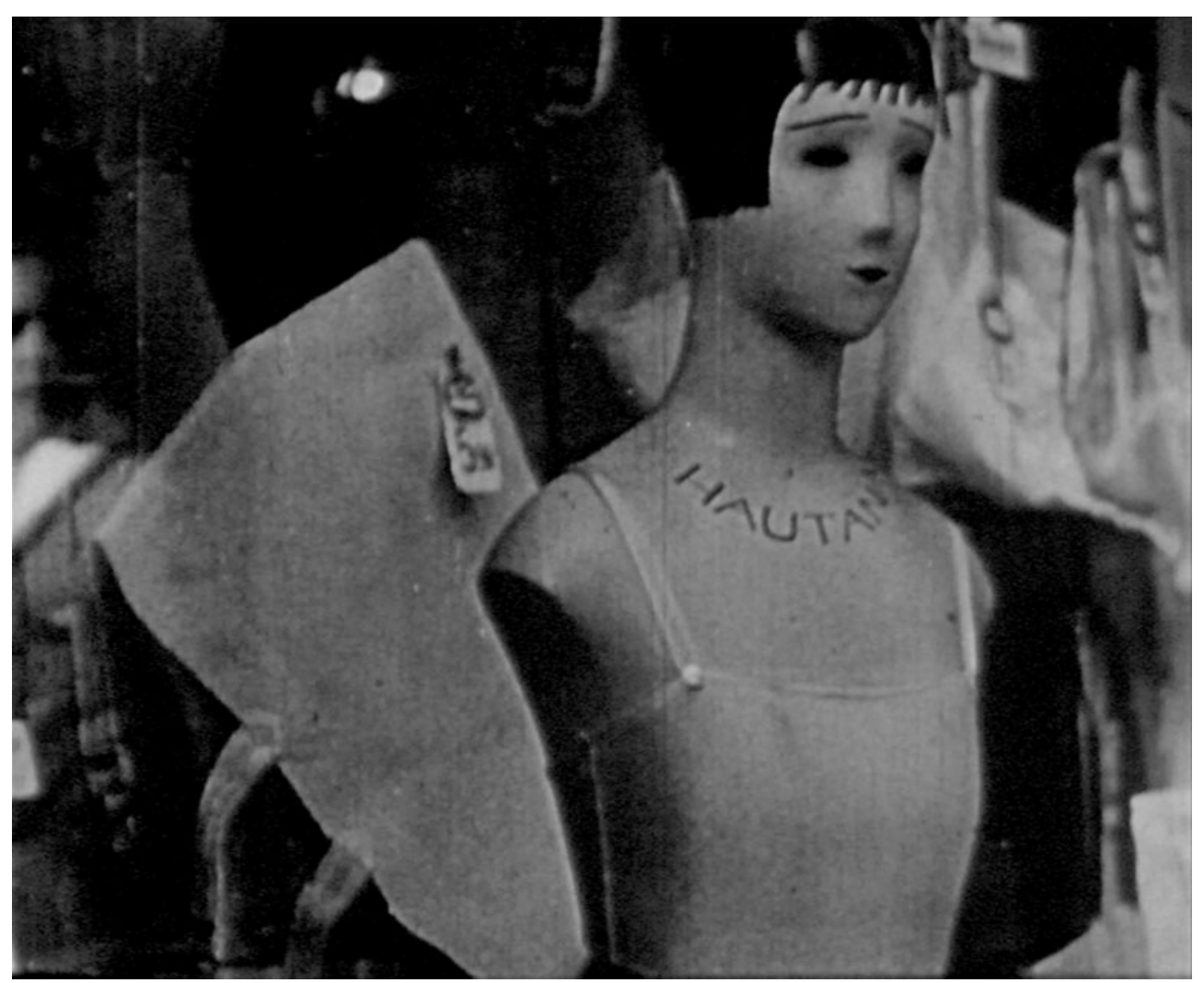

Still 13. From Hoogstraat (1928) in Stad zonder hart (1966).

Throughout the text, I have shown how the city as a system is distinct from but also part of its broader environment, to which it reacts. The articulation of this distinction is necessary for observations about the city. However, whereas a spatial distinction is a prerequisite for a system to exist, observations from within also need to draw distinctions regarding time to create a difference, in order for the system to direct its own development, or autopoiesis. Moving images and the archive have come in to serve this purpose.

I have paid special attention to the compilation film En toch... Rotterdam (1950), which was produced by Polygoon for the municipality and its business elite to promote its radically modern reconstruction plan after the city had been destroyed. Besides purposefully made recordings, En toch... constructed a memory by appropriating historical material, including images from The City That Never Rests (1928) that had been dismissed before as being out-dated. ${ }^{79}$ This material, however, became valuable after the war in order to create a historical narrative about the city's development. Collecting this and other material for the film suite —as En toch... Rotterdam was called—meant the onset of a municipal film archive. Both the film and the archive, however, also enabled Jan Schaper to reappropriate the material in order to criticize the results of the plan in his television documentary Stad zonder hart (1966).

Through the archive, the feedback loops_of films that informed the city, its officials, and citizens about developments in order to support plans or to change them-expanded from months to years and decades. Through their memory function, moving images enabled the city to monitor its long-term development, to match new conditions to past recordings. At the same time, films have fulfilled the function of oscillation, providing directions for the future. The terms memory and oscillation have been borrowed from Luhmann and they are analytically valuable, yet the case of 
F. Paalman, Visions of Reconstruction

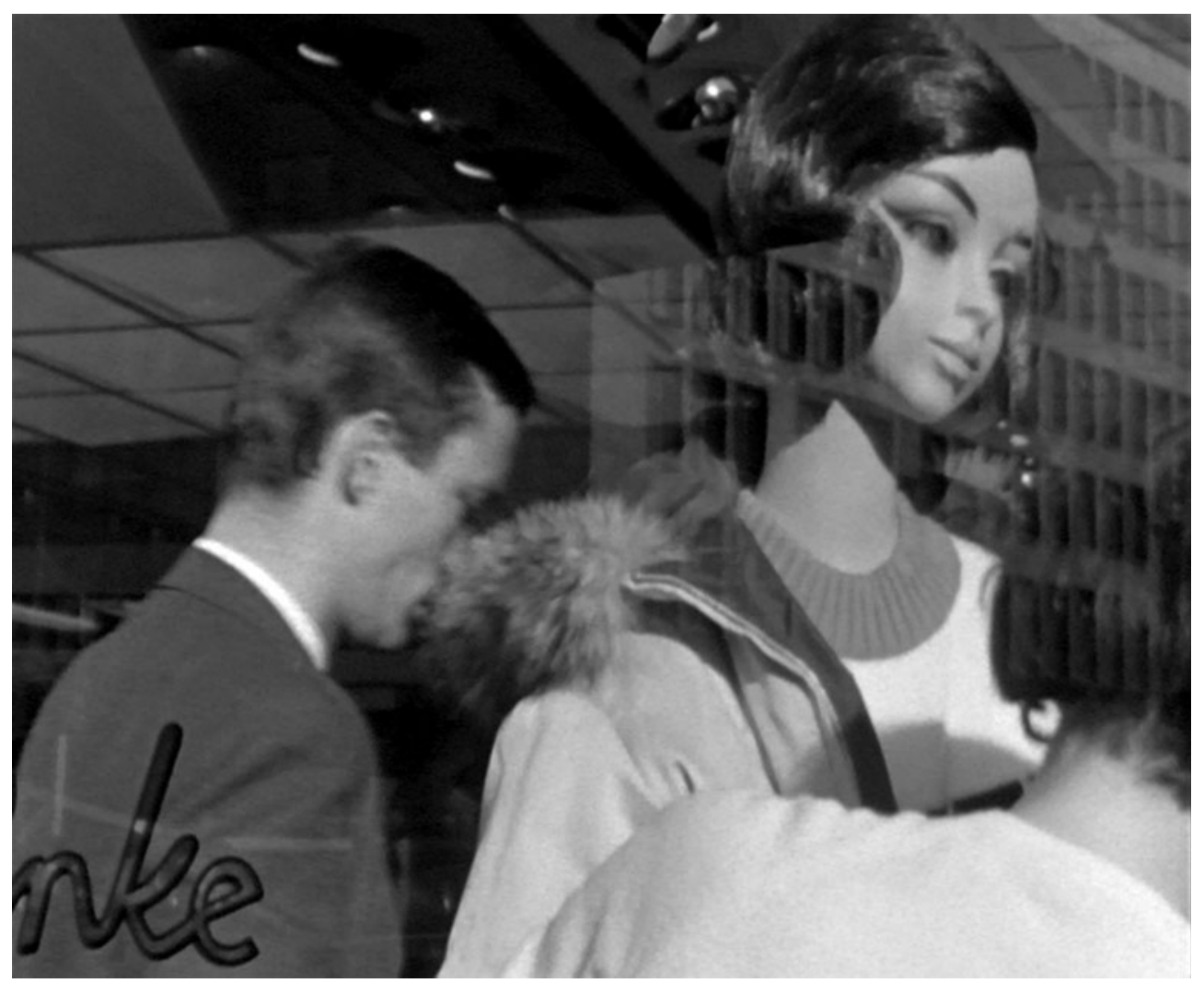

Still 14. Stad zonder hart (1966).

Rotterdam also suggests that, even though films may bend to either memory or oscillation, the functions remain intertwined. Memory also enables oscillation: found footage allows for juxtaposition of images, moving between perspectives, while it can also be used in different ways, from which new narrative lines are drawn. Oscillation in turn, creating perspectives for the future, also implies a new understanding of the past. This dynamic relationship between these cognitive functions fulfilled by moving images, is a characteristic of the city as an adaptive system. This is a modification of Luhmann's view, yet it also strengthens his claim that through these functions the notion of time itself is constructed.

The reasons of collecting, preserving, and using historical material, can be inverted later on, so that the same material can be used to construct counter-arguments about the past to serve another future. Rather than a paradox, it is a feature of a self-referential adaptive system that is the city. Such a system may have a relatively stable identity, according to Conti, but it is contested all the time through networks of people across different section of the city and particular people acting within these networks. This has been demonstrated by the dialectical development of the films Rotterdamse mijmeringen and En toch... Rotterdam, vis-à-vis the documentary Stad zonder hart. The layering of images and times discussed here correspond to a media archaeological understanding, in which the text, production, exhibition, and preservation of films and television programmes are seen together, connected to their specific purposes and uses within a particular environment, in which different films, or film suites, maintain discursive connections to one another.

Further research could make clear, through a comparative study, if the case of Rotterdam is indicative for a panEuropean development. Have the destroyed cities of Europe indeed been on the forefront of establishing local audiovisual archives, to compensate through images the loss of their physical structure, to safeguard their memory and identity, and to indicate directions for future development? What would this eventually mean for the place of such archives in the history of film and television? 
F. Paalman, Visions of Reconstruction

\section{Acknowledgements}

The author would like to thank historical society Roterodamum and the Stadsarchief Rotterdam, especially Anouk de Haas and Jantje Steenhuis.

\section{B i o graph y}

Floris Paalman, PhD, has trained in cultural anthropology, filmmaking, and film studies and has professional experience as a researcher and consultant in the fields of architecture and media. He is currently a lecturer in media archaeology, research methods, and film analysis, with a special interest in documentary and the cinematic city. 